\title{
Thermal evolution of the western South Atlantic and the adjacent continent during Termination 1
}

\author{
C. M. Chiessi ${ }^{1}$, S. Mulitza ${ }^{2}$, G. Mollenhauer ${ }^{2,3}$, J. B. Silva ${ }^{4}$, J. Groeneveld ${ }^{2}$, and M. Prange ${ }^{2}$ \\ ${ }^{1}$ School of Arts, Sciences and Humanities, University of São Paulo, São Paulo, Brazil \\ ${ }^{2}$ MARUM - Center for Marine Environmental Sciences, University of Bremen, Bremen, Germany \\ ${ }^{3}$ Alfred Wegener Institute for Polar and Marine Research, Bremerhaven, Germany \\ ${ }^{4}$ Institute of Geosciences, University of São Paulo, São Paulo, Brazil \\ Correspondence to: C. M. Chiessi (chiessi@usp.br)
}

Received: 6 November 2014 - Published in Clim. Past Discuss.: 15 December 2014

Revised: 22 May 2015 - Accepted: 23 May 2015 - Published: 22 June 2015

\begin{abstract}
During Termination 1, millennial-scale weakening events of the Atlantic meridional overturning circulation (AMOC) supposedly produced major changes in sea surface temperatures (SSTs) of the western South Atlantic, and in mean air temperatures (MATs) over southeastern South America. It has been suggested, for instance, that the Brazil Current (BC) would strengthen (weaken) and the North Brazil Current (NBC) would weaken (strengthen) during slowdown (speed-up) events of the AMOC. This antiphase pattern was claimed to be a necessary response to the decreased North Atlantic heat piracy during periods of weak AMOC. However, the thermal evolution of the western South Atlantic and the adjacent continent is so far largely unknown. Here we address this issue, presenting high-temporal-resolution SST and MAT records from the BC and southeastern South America, respectively. We identify a warming in the western South Atlantic during Heinrich Stadial 1 (HS1), which is followed first by a drop and then by increasing temperatures during the Bølling-Allerød, in phase with an existing SST record from the NBC. Additionally, a similar SST evolution is shown by a southernmost eastern South Atlantic record, suggesting a South Atlantic-wide pattern in SST evolution during most of Termination 1. Over southeastern South America, our MAT record shows a twostep increase during Termination 1, synchronous with atmospheric $\mathrm{CO}_{2}$ rise (i.e., during the second half of HS1 and during the Younger Dryas), and lagging abrupt SST changes by several thousand years. This delay corroborates the notion that the long duration of HS1 was fundamental in driving the Earth out of the last glacial.
\end{abstract}

\section{Introduction}

The thermal bipolar seesaw describes the warming occurring in the Southern Hemisphere due to diminished northward heat transport within the Atlantic Ocean when the Atlantic meridional overturning circulation (AMOC) is weakened (Mix et al., 1986; Stocker, 1998). This mechanism is particularly efficient for perturbations of the AMOC through positive anomalous freshwater fluxes in the high latitudes of the North Atlantic (Crowley, 1992; Manabe and Stouffer, 1988). Heinrich Stadial 1 (HS1) is probably the best example for a freshwater-forced AMOC reduction (McManus et al., 2004). It has been suggested that the southward-flowing Brazil Current (BC) might redirect the excess heat to the South Atlantic during times of AMOC slowdown (Crowley, 2011; Maier-Reimer et al., 1990). Yet, little is known about the thermal evolution of the western South Atlantic and the adjacent continent during Termination 1. The few available oceanic (e.g., Carlson et al., 2008) and continental (e.g., Bush et al., 2004) records do not show the necessary temporal resolution to appropriately resolve HS1. The lack of high-temporal-resolution records from the BC (Clark et al., 2012), for instance, hinders the evaluation of the previously hypothesized anti-phase behavior between the $\mathrm{BC}$ and the North Brazil Current (NBC) during periods of a stalled AMOC (Arz et al., 1999; Schmidt et al., 2012; Chiang et al., 2008).

Here we address this issue using an oceanic and a continental temperature record based on $\mathrm{Mg} / \mathrm{Ca}$ analyses in planktonic foraminifera and lipid analyses in continentally 

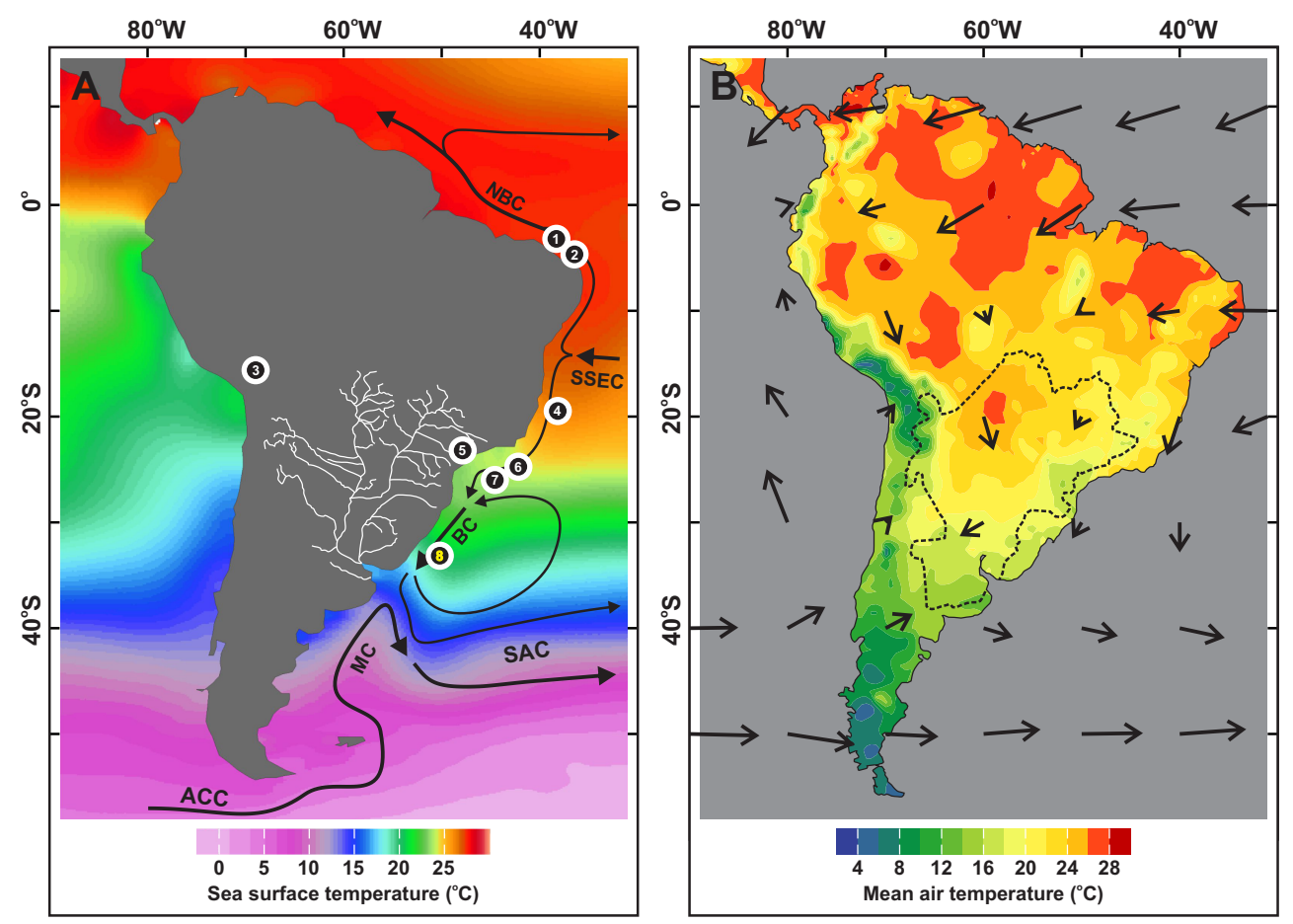

Figure 1. Location of the marine sediment core investigated in this study and other archives discussed in the text. (a) Annual mean sea surface temperatures (color shading, ${ }^{\circ} \mathrm{C}$ ) (Locarnini et al., 2010), and main annual mean surface ocean currents in the western South Atlantic (black arrows) (Peterson and Stramma, 1991; Stramma and England, 1999). Thin white lines depict the main tributaries of the La Plata River. Numbers indicate the locations of the following archives: (1) GeoB3104-1 and GeoB3117-1 (Arz et al., 1999), (2) GeoB3129-1/3911-3 (Arz et al., 1999; Weldeab et al., 2006), (3) Lake Consuelo (Bush et al., 2004), (4) GeoB3202-1 and GeoB3229-2 (Arz et al., 1999), (5) mean location of the sites described by Behling (2002), (6) SAN76 (Toledo et al., 2007), (7) KNR159-5-36GGC (Carlson et al., 2008), and (8) GeoB6211-2 (this study). ACC: Antarctic Circumpolar Current; BC: Brazil Current; MC: Malvinas Current; NBC: North Brazil Current; SAC: South Atlantic Current; SSEC: Southern South Equatorial Current. (b) Annual mean air temperature (color shading, $\left.{ }^{\circ} \mathrm{C}\right)($ Legates and Willmott, 1990), and annual mean low-level atmospheric circulation (black arrows) (Kalnay et al., 1996). The dashed black line depicts the La Plata River drainage basin. This figure was partly produced with Ocean Data View (Schlitzer, 2014).

derived organic matter, respectively. Our records come from a single marine sediment core collected off southeastern South America under the influence of the BC and spanning Termination 1 with high temporal resolution. Our data provide evidence for millennial-scale fluctuations in the oceanic temperature record associated with changes in AMOC strength, and a two-step increase in the continental temperature record associated with changes in atmospheric $\mathrm{CO}_{2}$.

\section{Regional setting}

\subsection{Western South Atlantic}

Upper level circulation in the subtropical western South Atlantic is dominated by the southward-flowing BC (Fig. 1a) (Peterson and Stramma, 1991; Stramma and England, 1999). The $\mathrm{BC}$ originates between 10 and $15^{\circ} \mathrm{S}$ from the bifurcation of the Southern South Equatorial Current (SSEC). At the bifurcation, the SSEC feeds both the BC and the northward flowing NBC (also termed the North Brazil Undercur- rent (Stramma et al., 1995) between the bifurcation and ca. $5^{\circ} \mathrm{S}$ ). Around $37^{\circ} \mathrm{S}$ the $\mathrm{BC}$ converges with the northwardflowing Malvinas Current (Olson et al., 1988), where both currents turn southeastward and flow offshore as the South Atlantic Current and the northern branch of the Antarctic Circumpolar Current, respectively. The position of the BrazilMalvinas Confluence varies seasonally between ca. 34 and $40^{\circ} \mathrm{S}$, with a northward penetration of the Malvinas Current during austral winter and early spring and a southward shift of the BC during austral summer and early autumn (Olson et al., 1988). In its uppermost $100 \mathrm{~m}$, the BC transports Tropical Water $\left(>20^{\circ} \mathrm{C}\right.$ and $\left.>36 \mathrm{psu}\right)$ in the mixed layer, and from ca. 100 until $600 \mathrm{~m}$ the BC transports South Atlantic Central Water $\left(6-20^{\circ} \mathrm{C}\right.$ and $\left.34.6-36 \mathrm{psu}\right)$ in the permanent thermocline (Locarnini et al., 2010; Antonov et al., 2010).

The deficit in the southward BC transport relative to what would be expected from the wind field is a consequence of the northward-directed upper branch of the thermohaline circulation (Stommel, 1957; Peterson and Stramma, 1991). The formation of North Atlantic Deep Water in the high latitudes 


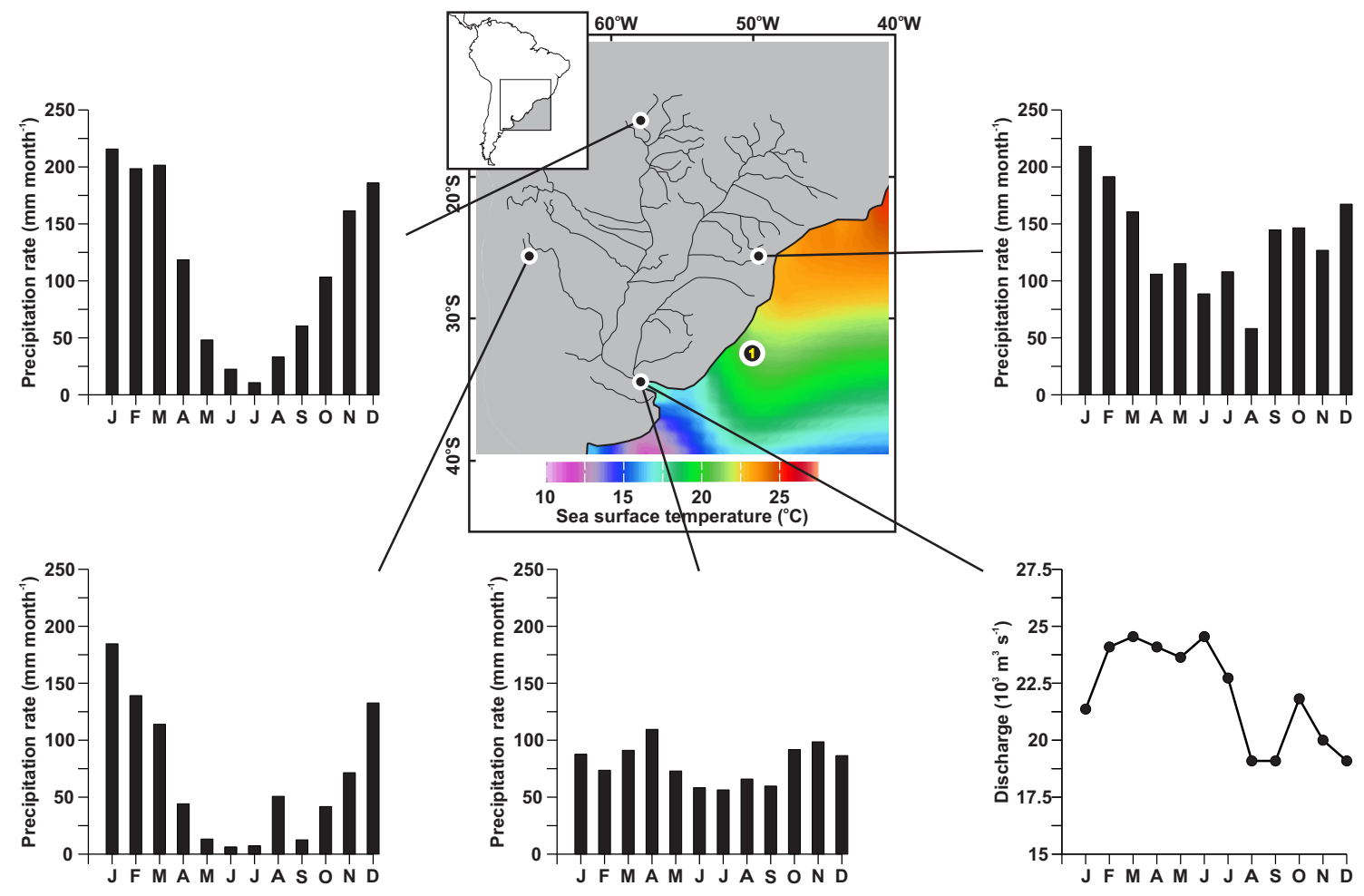

Figure 2. Histograms of the mean annual cycle of precipitation at selected stations in the La Plata River drainage basin (Xie and Arkin, 1997), and mean annual cycle of the La Plata River discharge on the lower right panel (Berbery and Barros, 2002). The color shading in the central panel depicts annual mean sea surface temperatures $\left({ }^{\circ} \mathrm{C}\right)$ (Locarnini et al., 2010). The number " 1 " in the central panel indicates the location of marine sediment core GeoB6211-2 (this study). This figure was partly produced with Ocean Data View (Schlitzer, 2014).

of the North Atlantic requires a net transfer of thermocline water from the South Atlantic to the North Atlantic together with net northward fluxes of intermediate and bottom waters (Rintoul, 1991; Peterson and Stramma, 1991). Thus, under modern conditions the NBC receives the larger portion (ca. $12 \mathrm{~Sv}$ ) of the SSEC volume transport when compared to the BC (ca. 4 Sv) (e.g., Stramma et al., 1990).

\subsection{Southeastern South America}

Throughout the year atmospheric circulation over southeastern South America is dominated by northerly winds (Fig. 1b) (Kalnay et al., 1996). During Southern Hemisphere summer, the South Atlantic convergence zone, a northwest-southeastoriented convective band along the northeastern boundary of the La Plata River drainage basin (LPRDB), and the South American low-level jet, a northwesterly low-level flow that transports moisture from the western Amazon to the LPRDB, are key features of the South American summer monsoon (Carvalho et al., 2004; Zhou and Lau, 1998). During Southern Hemisphere winter, equatorward incursions of mid-latitude cold dry air result in cyclonic storms (Vera et al., 2002). Precipitation in the LPRDB is dominated by Southern Hemisphere summer rainfall associated with the South American summer monsoon (Fig. 2) (Zhou and Lau, 1998;
Xie and Arkin, 1997). Correspondingly, maximum La Plata River discharge occurs in late Southern Hemisphere summer (Fig. 2). Winter precipitation triggered by occasional northward migration of extratropical cyclones results in less pronounced rainfall (Vera et al., 2002). Histograms of long-term mean average monthly precipitation display a strong Southern Hemisphere winter minimum (Fig. 2), particularly in the northwestern sector of the LPRDB, which supplies most of the particulate load of the La Plata River (Depetris and Kempe, 1993; Depetris et al., 2003).

Air temperatures at low atmospheric levels over South America are dominated by the Equator-to-pole thermal gradient (Fig. 1b) (Garreaud et al., 2009). The meridional temperature profile is rather flat between the Equator and $20^{\circ} \mathrm{S}$, centered around $20^{\circ} \mathrm{C}$. To the south of $20^{\circ} \mathrm{S}$, temperatures gradually decrease to $0^{\circ} \mathrm{C}$ over the southern tip of the continent. Zonal departures from this meridional gradient are relatively small to the east of the Andes, as is the case for the LPRDB. 
Table 1. Accelerator mass spectrometer radiocarbon ages and calibrated ages used to construct the age model of core GeoB6211-2.

\begin{tabular}{|c|c|c|c|c|c|c|c|}
\hline Lab ID & $\begin{array}{l}\text { Core } \\
\text { depth } \\
\text { (cm) }\end{array}$ & Species & $\begin{array}{l}\text { Radiocarbon } \\
\text { age } \pm 1 \sigma \\
\text { error (yr BP) }\end{array}$ & $\begin{array}{l}1 \sigma \text { calibrated } \\
\text { age range } \\
\text { (cal ka BP) }\end{array}$ & $\begin{array}{l}\text { Calibrated } \\
\text { age } \\
\text { (cal ka BP) }\end{array}$ & $\begin{array}{l}\text { Additional } \\
\text { age used in the } \\
\text { age model } \\
\text { (cal ka BP) }\end{array}$ & References \\
\hline NOSAMS75186 & 86 & $\begin{array}{l}\text { G. ruber and } \\
\text { G. sacculifer }\end{array}$ & $9370 \pm 40$ & $10.234-10.168$ & 10.2 & & Razik et al. (2013) \\
\hline KIA35163 & 95 & $\begin{array}{l}\text { G. ruber and } \\
\text { G. sacculifer }\end{array}$ & $9920 \pm 70$ & $10.997-10.762$ & 10.9 & & Razik et al. (2013) \\
\hline KIA35162 & $\begin{array}{l}98 \\
101\end{array}$ & $\begin{array}{l}\text { G. ruber and } \\
\text { G. sacculifer }\end{array}$ & $9810 \pm 110$ & $10.891-10.582$ & 10.75 & $10.85^{\mathrm{a}}$ & $\begin{array}{l}\text { Razik et al. (2013) } \\
\text { Razik et al. (2013) }\end{array}$ \\
\hline KIA30526 & 123 & $\begin{array}{l}\text { G. ruber and } \\
\text { G. sacculifer }\end{array}$ & $12600 \pm 70$ & $14.180-13.985$ & 14.1 & & Chiessi et al. (2008) \\
\hline KIA30525 & 218 & $\begin{array}{l}\text { G. ruber and } \\
\text { G. sacculifer }\end{array}$ & $13340 \pm 80$ & $15.599-15.306$ & 15.45 & & Chiessi et al. (2008) \\
\hline KIA35159 & 315 & $\begin{array}{l}\text { Mixed } \\
\text { planktonic } \\
\text { foraminiferab }\end{array}$ & $14520 \pm 30$ & $17.388-16.985$ & 17.2 & & This study \\
\hline KIA30524 & 358 & $\begin{array}{l}\text { Mixed } \\
\text { planktonic } \\
\text { foraminifera }^{b}\end{array}$ & $14860 \pm 90$ & $17.750-17.484$ & 17.6 & & Chiessi et al. (2008) \\
\hline KIA30531 & 448 & $\begin{array}{l}\text { Yoldia } \\
\text { riograndensis }\end{array}$ & $15590 \pm 100$ & $18.576-18.333$ & 18.45 & & Chiessi et al. (2008) \\
\hline KIA30530 & 583 & $\begin{array}{l}\text { Yoldia } \\
\text { riograndensis }\end{array}$ & $16400 \pm 120$ & $19.479-19.143$ & 19.3 & & Chiessi et al. (2008) \\
\hline
\end{tabular}

${ }^{\text {a }}$ Interpolated value between the calibrated radiocarbon ages at 95 and $101 \mathrm{~cm}$ depth. ${ }^{\mathrm{b}}$ Mixed planktonic foraminifera contained G. ruber (pink and white), G. sacculifer, G. bulloides, G. siphonifera, T. quinqueloba, G. glutinata, G. uvula, G. conglobatus, and G. falconensis.

\section{Material and methods}

\subsection{Marine sediment core}

We investigated sediment core GeoB6211-2 (Schulz et al., 2001; Wefer et al., 2001), collected from the continental slope off southeastern South America $\left(32.51^{\circ} \mathrm{S}, 50.24^{\circ} \mathrm{W}\right.$; $657 \mathrm{~m}$ water depth; $774 \mathrm{~cm}$ long) (Figs. 1a, 2). The gravity core was raised at the Rio Grande Cone, a major sedimentary feature in the western Argentine Basin (Schulz et al., 2001). Because our focus here is Termination 1, we analyzed the section from 86 until $583 \mathrm{~cm}$ core depth that corresponds to the period from 10.2 until 19.3 cal ka BP (see Sect. 4.1 below).

One-meter-long sections of core GeoB6211-2 were longitudinally split and described onboard, and then stored at $4{ }^{\circ} \mathrm{C}$. Visual inspection of core GeoB6211-2 does not provide evidence for depositional or erosive disturbance (Wefer et al., 2001). Onshore, the last deglaciation section of the core was sampled at $1 \mathrm{~cm}$ intervals. Samples for radiocarbon, $\mathrm{Mg} / \mathrm{Ca}$, and stable oxygen isotope $\left(\delta^{18} \mathrm{O}\right)$ analyses were wet-sieved, oven-dried at $50^{\circ} \mathrm{C}$, and the residues from the $150 \mu \mathrm{m}$ size sieve were stored in glass vials. Hand picking of foraminiferal tests was performed under a binocular microscope. Samples for lipid analyses were stored at $4{ }^{\circ} \mathrm{C}$ until processing.

\subsection{Radiocarbon analyses and age model}

The age model of core GeoB6211-2 is based on nine accelerator mass spectrometry radiocarbon ages (Table 1, Fig. 3). Five ages are based on tests of the shallow-dwelling planktonic foraminifera Globigerinoides ruber (pink and white) and Globigerinoides sacculifer, while the remaining four ages are based either on mixed planktonic foraminifera (i.e., two ages) or epibenthic bivalve shells (i.e., two ages). Apart from the age obtained at $315 \mathrm{~cm}$ core depth, all ages were previously published by Chiessi et al. (2008) and Razik et al. (2013). For each sample, we collected around $10 \mathrm{mg}$ of $\mathrm{CaCO}_{3}$ from the sediment fraction larger than $150 \mu \mathrm{m}$. One of the samples was measured at the National Ocean Sciences Accelerator Mass Spectrometry Facility at Woods Hole (USA), while the other eight were measured at the Leibniz Laboratory for Radiometric Dating and Stable Isotope Research at Kiel (Germany). All radiocarbon ages were calibrated with the calibration curve Marine13 (Reimer et al., 2013) with the software Calib 7.0 (Stuiver and Reimer, 1993). Following the arguments from Chiessi et al. (2008) we decided not to use a specific reservoir age to the radiocarbon ages based on epibenthic bivalve shells. Also, no additional marine reservoir correction was applied because our core site is located far from upwelling zones and significantly 
to the north of the Brazil-Malvinas Confluence, both being places where corrections are typically necessary (Reimer and Reimer, 2001). All ages are indicated as calibrated years before present (cal a BP; present is AD 1950), except where noted otherwise. To construct the age model, we linearly interpolated the calibrated ages. For each dated depth we used in the interpolation the mean value from the $1 \sigma$ range of the calibrated age.

\subsection{Mg / Ca analyses and sea surface temperatures}

Around 40 tests of $G$. ruber (white, sensu stricto according to Wang, 2000) within the size range 250-350 $\mu \mathrm{m}$ were used for $\mathrm{Mg} / \mathrm{Ca}$ analyses. Analyses were performed at approximately every centimeter between 86 and $123 \mathrm{~cm}$ core depth, and at approximately every $4 \mathrm{~cm}$ below $123 \mathrm{~cm}$ core depth. Different spacing was applied to compensate for the lower sedimentation rates in the section $86-123 \mathrm{~cm}$ core depth as compared to the section $123-583 \mathrm{~cm}$ core depth (see Sect. 4.1 below). After the tests had been gently crushed, shell fragments were cleaned according to the standard cleaning protocol for foraminiferal $\mathrm{Mg} / \mathrm{Ca}$ analyses suggested by Barker et al. (2003) and slightly modified by Groeneveld and Chiessi (2011). Before dilution, samples were centrifuged for $10 \mathrm{~min}(6000 \mathrm{rpm})$ to exclude any remaining insoluble particles from the analyses. Samples were diluted with Seralpur water before analysis with an inductively coupled plasma optical emission spectrometer (ICP-OES) (Agilent Technologies, 700 Series with autosampler (ASX-520 Cetac) and micro-nebulizer) at the MARUM - Center for Marine Environmental Sciences, University of Bremen, Germany. Instrumental precision of the ICP-OES was monitored by analysis of an in-house standard solution with a $\mathrm{Mg} / \mathrm{Ca}$ of $2.93 \mathrm{mmol} \mathrm{mol}^{-1}$ after every five samples (long-term standard deviation of $0.026 \mathrm{mmol} \mathrm{mol}^{-1}$ or $0.91 \%$ ). To allow inter-laboratory comparison we analyzed an international limestone standard (ECRM752-1) with a reported $\mathrm{Mg} / \mathrm{Ca}$ of $3.75 \mathrm{mmol} \mathrm{mol}^{-1}$ (Greaves et al., 2008). The long-term average of the ECRM752-1 standard, which was routinely analyzed twice before each batch of 50 samples in every session, is $3.78 \mathrm{mmol} \mathrm{mol}^{-1}\left(1 \sigma=0.066 \mathrm{mmol} \mathrm{mol}^{-1}\right)$. Analytical error based on three replicate measurements of each sample for $G$. ruber was $0.14 \%\left(1 \sigma=0.004 \mathrm{mmol} \mathrm{mol}^{-1}\right)$ for $\mathrm{Mg} / \mathrm{Ca}$. To convert $\mathrm{Mg} / \mathrm{Ca}$ into sea surface temperatures (SSTs), we used the calibration equation of Anand et al. (2003) for G. ruber (white) in the size range 250-350 $\mu \mathrm{m}$ with no pre-assumed exponential constant:

$\mathrm{Mg} / \mathrm{Ca}=0.34 \exp (0.102 \times \mathrm{SST})$.

The propagation of uncertainties typically results in $1 \sigma$ error of about $1^{\circ} \mathrm{C}$ for SST (Mohtadi et al., 2014).
According to Hönisch et al. (2013), the small sensitivity of G. ruber $\mathrm{Mg} / \mathrm{Ca}$ to changes in salinity (i.e., $3.3 \pm 1.7 \%$ per salinity unit) supports the use of this paleotemperature proxy given the range of salinity change in our study area (see Sect. 4.3 below).

We measured $\mathrm{Mg} / \mathrm{Ca}$ in tests of G. ruber (white) because it dwells in the uppermost water column and reflects mixed-layer conditions (Chiessi et al., 2007). Moreover, $G$. ruber (white) records austral hemisphere summer conditions at our core site (Fraile et al., 2009a; Lombard et al., 2011), with no significant change in seasonal preference during the Last Glacial Maximum (LGM) (Fraile et al., 2009b). Furthermore, the mean $\mathrm{Mg} / \mathrm{Ca}$-based SST (i.e., $23.1^{\circ} \mathrm{C}$ ) obtained for the uppermost two samples of multicore GeoB6211-1 (collected in the same site as gravity core GeoB6211-2) compares favorably with the modern mean summer SST in the top $20 \mathrm{~m}$ of the local water column (i.e., $24.1^{\circ} \mathrm{C}$ ) and differs considerably from modern mean winter SST (i.e., $17.8^{\circ} \mathrm{C}$ ), corroborating the austral hemisphere summer signal recorded by G. ruber (white) (Chiessi et al., 2014).

\subsection{Stable oxygen isotope analyses and sea surface salinities}

Ten hand-picked tests of $G$. ruber (white, sensu stricto according to Wang, 2000) within the size range $250-350 \mu \mathrm{m}$ from approximately every centimeter of core GeoB62112 were used for $\delta^{18} \mathrm{O}$ analyses. Results between 448 and $123 \mathrm{~cm}$ core depth were previously published by Chiessi et al. (2009). Stable oxygen isotope analyses were performed on a Finnigan MAT 252 mass spectrometer equipped with an automatic carbonate preparation device at MARUM. Isotopic results were calibrated relative to the Vienna Pee Dee Belemnite (VPDB) using the NBS19 standard. The standard deviation of the laboratory standard was lower than $0.07 \%$ o for the measuring period.

To calculate the $\delta^{18} \mathrm{O}$ of continental-ice-volume-corrected surface sea water $\left(\delta^{18} \mathrm{O}_{\mathrm{ivc}-\mathrm{ssw}}\right)$, a proxy for relative sea surface salinity, we used (i) our G. ruber $\mathrm{Mg} / \mathrm{Ca}$ SST and $\delta^{18} \mathrm{O}$; (ii) the paleotemperature equation from Mulitza et al. (2003) for G. ruber (white),

$$
\mathrm{SST}\left({ }^{\circ} C\right)=-4.44 \times\left(\delta^{18} \mathrm{O}_{G . r u b e r}-\delta^{18} \mathrm{O}_{\mathrm{sw}}\right)+14.20
$$

(iii) the VPDB to Vienna Standard Mean Ocean Water conversion factor from Hut (1987); (iv) the sea-level curve from Lambeck and Chappell (2001); and (v) the global average change in $\delta^{18} \mathrm{O}_{\mathrm{sw}}$ since the LGM from Schrag et al. (2002). The sea-level curve from Lambeck and Chappell (2001) is consistent with the timing of meltwater pulse 1A reported by Deschamps et al. (2012) (14.5 and $14.6 \mathrm{cal} \mathrm{ka} \mathrm{BP,} \mathrm{re-}$ spectively). The propagation of uncertainties typically results in $1 \sigma$ error of about $0.3 \%$ for $\delta^{18} \mathrm{O}_{\text {ivc-ssw }}$ (Mohtadi et al., 2014). 


\subsection{Lipid analyses and continental mean air temperatures}

Lipid analyses were performed at approximately every $6 \mathrm{~cm}$. Lipid extraction of freeze-dried powdered samples was performed by the use of ultrasonic probes. Extracts were saponified and further separated on Bond Elut $\mathrm{SiO}_{2}$ columns. Polar fractions containing glycerol dialkyl glycerol tetraethers (GDGTs) were eluted with $2 \mathrm{~mL}$ of $\mathrm{MeOH}$. Prior to analysis by high-performance liquid chromatography/atmospheric pressure chemical ionization mass spectrometry (HPLC/APCI-MS), samples were filtered through a $4 \mu \mathrm{m}$ pore size PTFE filter and dissolved in hexane/isopropanol $(99: 1 ; v / v)$. An Agilent 1200 series HPLC/APCI-MS system equipped with a Grace Prevail Cyano column $(150 \mathrm{~mm} \times 2.1 \mathrm{~mm} ; 3 \mu \mathrm{m})$ was used, and separation was achieved in normal phase using the method described by Hopmans et al. (2004).

Mean air temperature (MAT) was estimated according to Peterse et al. (2012). GDGTs with the following protonated molecular ion masses were quantified: 1022 (Ia), 1020 (Ib), 1018 (Ic); 1036 (IIa), 1034 (IIb), 1032 (IIc); 1050 (IIIa). Ratios of peak areas were used to calculate the methylation of branched tetraether (MBT') and cyclization of branched tetraether (CBT) indices as follows:

$$
\begin{aligned}
& \text { MBT }^{\prime}=\frac{(I a+I b+I c)}{(I a+\text { Ib }+ \text { Ic }+ \text { IIa }+ \text { IIb }+ \text { IIc }+ \text { IIIa })}, \\
& \text { CBT }=-\log \left[\left(\frac{\text { Ib }+ \text { IIb }}{\text { Ia }+ \text { IIa }}\right)\right] .
\end{aligned}
$$

Index values calculated using Eqs. (3) and (4) were subsequently converted to MAT estimates according to

$\operatorname{MAT}\left({ }^{\circ} C\right)=0.81-5.67 \times \mathrm{CBT}+31.0 \times \mathrm{MBT}$.

The production of GDGTs by some uncharacterized microbial community in marine sediments has gained recent attention (e.g., Zhu et al., 2011). For in situ production in the marine realm, the authors consistently describe an increase in the relative abundance of those GDGTs containing cyclopentane moieties (e.g., GDGT Ic and GDGT IIc) as well as a decrease in the relative abundance of the compounds GDGT Ia and GDGT IIa. We carefully screened our results for a similar behavior.

Temperature estimates are thought to reflect mean annual air temperature (Peterse et al., 2012). During Termination 1, our core site received terrigenous material discharged from the La Plata River drainage basin (LPRDB) as attested by Nd isotopes (Lantzsch et al., 2014). Within the LPRDB, most of the suspended load (Depetris et al., 2003) and particulate organic matter (Depetris and Kempe, 1993) originates from the Bermejo River sub-basin, located in the northwest domain. The amount of river suspended load corresponds to the discharge (Depetris et al., 2003), and most of the particulate organic matter is soil-derived (Depetris and Kempe, 1993).

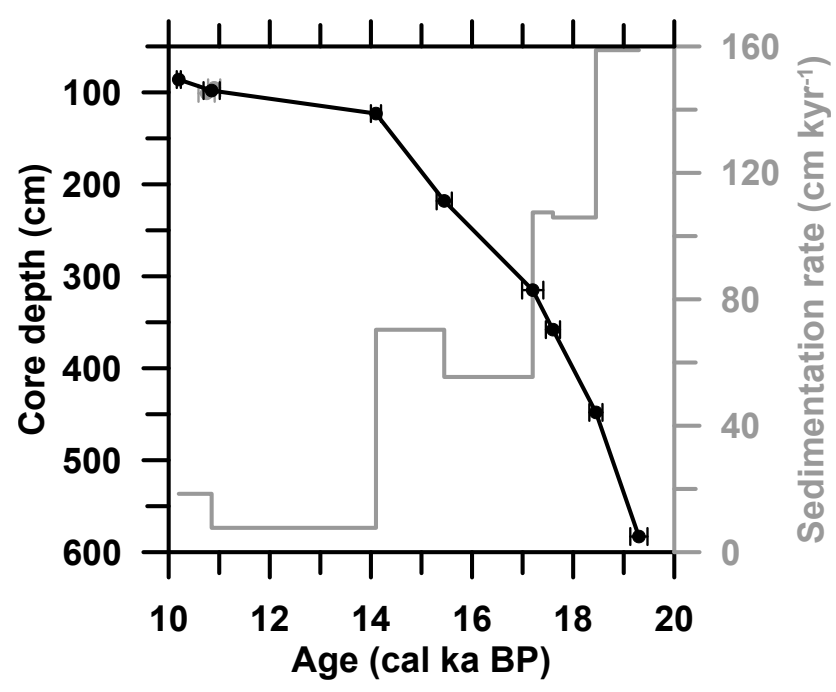

Figure 3. Age model and sedimentation rates for marine sediment core GeoB6211-2.

Thus, we expect our MAT record to represent a LPRDBintegrated signal with a predominant contribution from its northwestern domain.

\section{Results}

\subsection{Radiocarbon analyses and age model}

The investigated section (i.e., $86-583 \mathrm{~cm}$ core depth) of core GeoB6211-2 recorded the period between 10.2 and 19.3 cal ka BP (Table 1, Fig. 3). The Marine13 calibration curve produced very similar ages (i.e., difference smaller than $0.2 \mathrm{kyr}$ ) when compared to the previously published values (Chiessi et al., 2008; Razik et al., 2013) calibrated with Marine04 (Hughen et al., 2004) and Marine09 (Reimer et al., 2009). Thus, the age model used here is very similar to the age models published by Chiessi et al. (2008) between 19.3 and $14.1 \mathrm{cal} \mathrm{ka} \mathrm{BP}$, and by Razik et al. (2013) between 14.1 and $10.2 \mathrm{cal} \mathrm{ka} \mathrm{BP.}$

Sedimentation rates of the investigated section of core GeoB6211-2 show a two-step decrease from the LGM to the early Holocene (Fig. 3). Mean values decrease from ca. 160 to $80 \mathrm{~cm} \mathrm{kyr}^{-1}$ at $18.45 \mathrm{cal} \mathrm{ka} \mathrm{BP}$, and from ca. 80 to $10 \mathrm{~cm} \mathrm{kyr}^{-1}$ at $14.1 \mathrm{cal} \mathrm{ka} \mathrm{BP.}$

Considering the sampling strategy and the sedimentation rates for core GeoB6211-2, the mean temporal resolution is ca. 30 years for $\mathrm{Mg} / \mathrm{Ca}$ analyses, ca. 10 years for $\delta^{18} \mathrm{O}$ analyses, and ca. 80 years for lipid analyses for the period before $18.45 \mathrm{cal} \mathrm{ka} \mathrm{BP}$; ca. 60 years for $\mathrm{Mg} / \mathrm{Ca}$ analyses, ca. 15 years for $\delta^{18} \mathrm{O}$ analyses, and ca. 70 years for lipid analyses for the period between 18.45 and $14.1 \mathrm{cal} \mathrm{ka} \mathrm{BP}$; and ca. 120 years for $\mathrm{Mg} / \mathrm{Ca}$ analyses, ca. 105 years for $\delta^{18} \mathrm{O}$ analyses, and ca. 555 years for lipid analyses for the period after 14.1 cal ka BP. 


\section{2 $\mathrm{Mg} / \mathrm{Ca}$ analyses and sea surface temperatures}

$\mathrm{Mg} / \mathrm{Ca}$ values from $G$. ruber range from 2.50 to $3.60 \mathrm{mmol} \mathrm{mol}^{-1}$ and are equivalent to 19.5 and $23.1^{\circ} \mathrm{C}$, respectively (Fig. 4b). Reconstructed SST increase since the LGM (averaging $20.6^{\circ} \mathrm{C}$ ) until ca. $18 \mathrm{cal} \mathrm{ka} \mathrm{BP}$, remaining roughly constant (averaging $21.9^{\circ} \mathrm{C}$ ) until ca. $16 \mathrm{cal} \mathrm{ka}$ BP. A marked SST drop reaching minimum value $\left(20.4{ }^{\circ} \mathrm{C}\right)$ at ca. $15.5 \mathrm{cal} \mathrm{ka} \mathrm{BP}$ ends the period of relatively stable SST. A double-peak structure culminating at ca. 15 cal ka BP $\left(23.0^{\circ} \mathrm{C}\right)$ and ca. $13 \mathrm{cal} \mathrm{ka} \mathrm{BP}\left(22.9^{\circ} \mathrm{C}\right)$ was followed by low temperatures (averaging $21.7^{\circ} \mathrm{C}$ ) until ca. 11.9 cal ka BP. After that, the record is characterized by oscillating SST (averaging $22.2{ }^{\circ} \mathrm{C}$ ) SST. Thus, the deglacial SST rise is ca. $1.6^{\circ} \mathrm{C}$.

\subsection{Stable oxygen isotope analyses and sea surface salinities}

Values of G. ruber $\delta^{18} \mathrm{O}$ show a stepwise decrease from $0.75 \%$ o during the LGM to $-0.06 \%$ during the early Holocene (Fig. 4c). There are three major steps, and they occurred at ca. $15.5,13.5$ and $11.5 \mathrm{cal} \mathrm{ka} \mathrm{BP.}$

Ice-volume-corrected $\delta^{18} \mathrm{O}_{\text {ssw }}$ values range from 0.88 to $2.15 \%$ (Fig. 4d). From the LGM until ca. 14 cal ka BP, temporal changes in $\delta^{18} \mathrm{O}_{\mathrm{ivc}-\mathrm{ssw}}$ are similar to the changes described for SST. After that, the record is marked by roughly constant values (averaging $1.65 \%$ ) until $11.5 \mathrm{cal} \mathrm{ka} \mathrm{BP}$ and a rather large variability around $1.47 \%$ o during the early Holocene.

\subsection{Lipid analyses and continental mean air temperatures}

We first examined our data set for indications of marine insitu production of GDGTs as described in Sect. 3.5, which was not the case (Chiessi et al., 2015b). Then, we calculated continental MAT values that range from $11.5^{\circ} \mathrm{C}$ at $18.0 \mathrm{cal} \mathrm{ka} \mathrm{BP}$ to $14.9^{\circ} \mathrm{C}$ at $11.5 \mathrm{cal} \mathrm{ka} \mathrm{BP}$ (Fig. 4e). Reconstructed MATs show a small gradual increase from the base of the record until ca. $16.5 \mathrm{cal} \mathrm{ka} \mathrm{BP}$, when a sharp increase of ca. $1.1^{\circ} \mathrm{C}$ takes place. Temperatures remain relatively stable until ca. $12.5 \mathrm{cal} \mathrm{ka} \mathrm{BP}$, when an increase of ca. $1.0^{\circ} \mathrm{C}$ within ca. $1 \mathrm{kyr}$ was recorded. After that, stable MATs characterize the record until the early Holocene. Although our MAT record does not cover the LGM, the deglacial MAT rise calculated using the averaged value for the oldest and youngest 500 -year values of our time series is $2.5^{\circ} \mathrm{C}$. The marked decrease in the mean temporal resolution of our MAT record after 14.1 cal ka BP that shifts from ca. 70 to ca. 555 years is worthy of note. This has to be considered while interpreting the MAT trends described for the period after $14.1 \mathrm{cal} \mathrm{ka} \mathrm{BP.}$

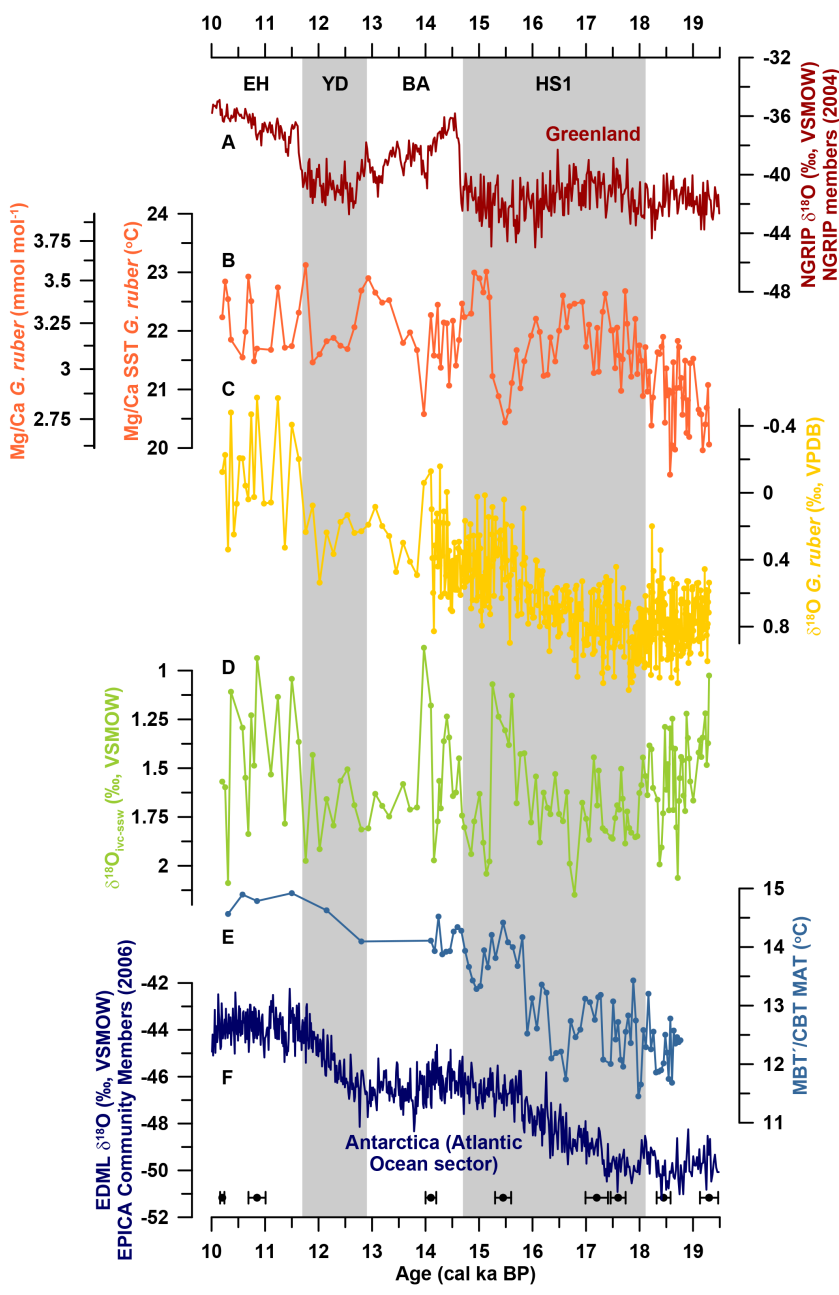

Figure 4. Proxy records for the western South Atlantic and southeastern South America spanning Termination 1 based on marine sediment core GeoB6211-2 together with ice core temperature records. (a) North Greenland Ice Core Project (NGRIP members, 2004) $\delta^{18} \mathrm{O}$ plotted versus the Greenland Ice Core Chronology 2005 (GICC05) (Rasmussen et al., 2006). (b) GeoB6211-2 Globigerinoides ruber (white) $\mathrm{Mg} / \mathrm{Ca}$ and $\mathrm{Mg} / \mathrm{Ca}$-based sea surface temperatures. (c) GeoB6211-2 Globigerinoides ruber (white) stable oxygen isotope $\left(\delta^{18} \mathrm{O}\right)$ (partially from Chiessi et al., 2009). (d) GeoB6211-2 continental-ice-volume-corrected oxygen isotopic composition of surface sea water $\left(\delta^{18} \mathrm{O}_{\mathrm{ivc}-\mathrm{ssw}}\right)$, a proxy for salinity. (e) GeoB6211-2 methylation of branched tetraether (MBT')- and cyclization of branched tetraether (CBT)-based mean air temperature (MAT). (f) EPICA Dronning Maud Land (EPICA Community Members, 2006) $\delta^{18} \mathrm{O}$ plotted versus its original chronology. Black symbols at the bottom of the panel depict calibrated radiocarbon ages used to produce the age model for GeoB6211-2. Grey vertical bars depict Heinrich Stadial 1 (HS1) (Sarnthein et al., 2001) and the Younger Dryas (YD) (Rasmussen et al., 2006). BA: BøllingAllerød; EH: early Holocene. 


\section{Discussion}

The two major decreases in sedimentation rates found in GeoB6211-2 are remarkably synchronous (within age model uncertainties) with outstanding events of sea-level rise related to meltwater pulses that occurred at ca. 19 and $14.6 \mathrm{cal} \mathrm{ka} \mathrm{BP}$ (Deschamps et al., 2012; Yokoyama et al., 2000). The sea-level drop preceding the LGM shifted the coastline towards our core site. With the resulting narrow continental shelf, the large sediment supply of the La Plata River was directed to the Rio Grande Cone via the La Plata paleo-valley, which was responsible for the high sedimentation rates typical for the lowermost section of core GeoB6211-2 (Fig. 3) (Chiessi et al., 2008; Lantzsch et al., 2014). The stepwise rise in sea level following the LGM caused abrupt displacements of the coastline towards the continent trapping a large amount of the La Plata River sediment supply on the shelf and controlling the stepwise decrease in sedimentation rate at our site (Chiessi et al., 2008; Lantzsch et al., 2014). Because of the high sedimentation rates (i.e., ca. $100 \mathrm{~cm} \mathrm{kyr}^{-1}$ ) found between the LGM and 14.1 cal ka BP, core GeoB6211-2 is particularly well suited to investigate $\mathrm{HS} 1$.

\subsection{Sea surface temperatures and salinities of the western South Atlantic during Termination 1}

The high SSTs reconstructed for our western South Atlantic site between 18 and $16 \mathrm{cal} \mathrm{ka} \mathrm{BP}$ as well as the peak in SST at ca. 15 cal ka BP (Fig. 4b) fall within HS1, as defined by Sarnthein et al. (2001). It has been suggested that, during HS1, a strong slowdown of the AMOC (Fig. 5b) (McManus et al., 2004) produced by a positive anomalous freshwater discharge into the high latitudes of the North Atlantic (Bond et al., 1992) would have been responsible for a decreased cross equatorial heat transport in the Atlantic (Fig. 5a) (Bard et al., 2000). Under a sluggish AMOC, the residual heat not transported to the North Atlantic would be trapped in the Southern Hemisphere (Broecker, 1998; Crowley, 1992). Many water-hosing model experiments that show a strong decrease in AMOC strength have suggested that the Southern Hemisphere warming should have affected the surface layer of the BC (Kageyama et al., 2013; Stouffer et al., 2006). This warming has been suggested for experiments under both LGM and preindustrial boundary conditions. Here we show the first record that corroborates this suggestion (Fig. 4b). We propose that the surface layer of the BC acted as a conduit and storage volume for part of the heat not transported to the North Atlantic during HS1 that was eventually shunted towards higher latitudes in the South Atlantic (Barker et al., 2009; Anderson et al., 2009). Moreover, the marked drop in our SST record reaching minimum values at ca. $15.5 \mathrm{cal} \mathrm{ka}$ $\mathrm{BP}$ could be related to an intervening warm spell registered within HS1 in the North Atlantic mid-latitudes (Martrat et al., 2014). We hypothesize that millennial-scale changes as-

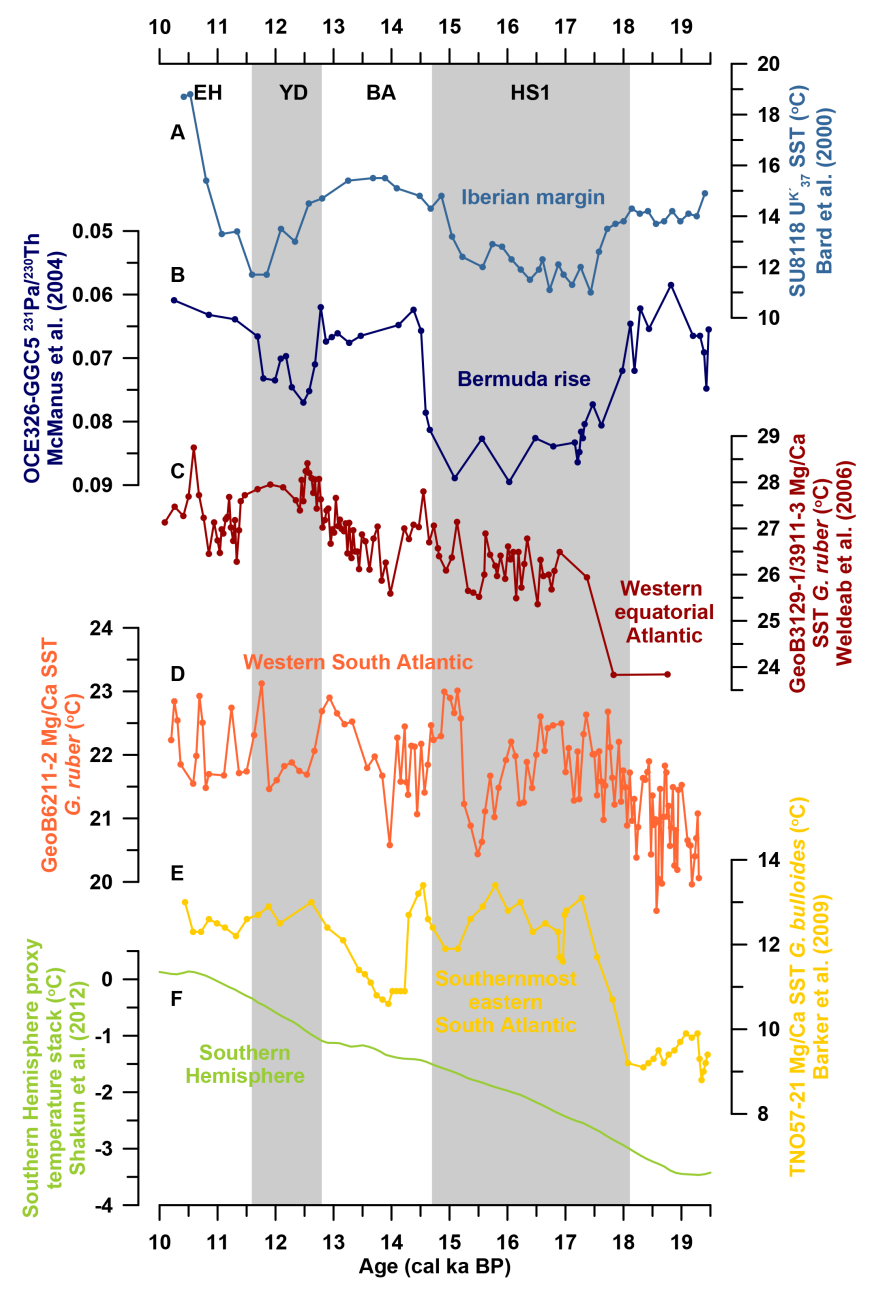

Figure 5. Millennial-scale variability of sea surface temperatures of the Brazil Current spanning Termination 1 compared to available circum-Atlantic records. (a) SU8118 $U_{37}^{K^{\prime}}$-based sea surface temperatures (Bard, 2000). (b) OCE326-GGC5 ${ }^{231} \mathrm{~Pa} /{ }^{230} \mathrm{Th}$-based record of the strength of the Atlantic meridional overturning circulation (McManus et al., 2004). (c) GeoB3129-1/3911-3 Globigerinoides ruber (white) $\mathrm{Mg} / \mathrm{Ca}$-based sea surface temperatures (Weldeab et al., 2006). (d) GeoB6211-2 Globigerinoides ruber (white) $\mathrm{Mg} / \mathrm{Ca}$-based sea surface temperatures. (e) TN057-21 Globigerina bulloides $\mathrm{Mg}$ / Ca-based sea surface temperatures (Barker et al., 2009). (f) Southern Hemisphere proxy temperature stack (Shakun et al., 2012). Grey vertical bars depict Heinrich Stadial 1 (HS1) (Sarnthein et al., 2001) and the Younger Dryas (YD) (Rasmussen et al., 2006). BA: Bølling-Allerød; EH: early Holocene.

sociated with Termination 1 (e.g., HS1) affected the BC, and that centennial-scale fluctuations (e.g., internal structure of HS1) were also registered. However, we primarily discuss the millennial-scale events because of age model uncertainties.

Interestingly, the other high-temporal-resolution $\mathrm{Mg} / \mathrm{Ca}$ based SST record from the western South Atlantic covering Termination 1 shows similar changes in SST during 
HS1 (Figs. 1a, 5c) (Weldeab et al., 2006). This core (i.e., GeoB3129-1/3911-3) was collected off NE Brazil at $4.61^{\circ} \mathrm{S}$, thus under the influence of the NBC. The similarity in SST between both western South Atlantic records goes beyond HS1, and is also valid for the SST drop with minimum values at ca. $14 \mathrm{cal} \mathrm{ka} \mathrm{BP,} \mathrm{and} \mathrm{peak} \mathrm{SST} \mathrm{at} \mathrm{ca.} 13 \mathrm{cal} \mathrm{ka} \mathrm{BP,} \mathrm{during}$ the Bølling-Allerød (BA). Thus, our SST record (from the BC) together with the SST record from Weldeab et al. (2006) (from the NBC) suggests a generally in-phase behavior of the $\mathrm{BC}$ and the $\mathrm{NBC}$ regions during HS1 and the BA. This contradicts the BC-NBC anti-phase relationship suggested by Arz et al. (1999), at least concerning SST, since we have no proxy to assess current strength.

It is worthy of note that Arz et al. (1999) based their suggestion exclusively on $\delta^{18} \mathrm{O}$ records of planktonic foraminifera. The more negative excursion in foraminiferal $\delta^{18} \mathrm{O}$ that those authors reported during HS1 for the cores collected under the influence of the BC (i.e., GeoB32292, GeoB3202-1) when compared to the less negative excursion reported for the cores under the influence of the NBC (i.e., GeoB3104-1, GeoB3117-1, GeoB3129-1/3911-3, GeoB3176-1) supported the notion that the sluggish AMOC would have triggered a weakening in the NBC and a strengthening in the BC (Fig. 1a). This would have been responsible for the low HS1 meridional gradient in the $\delta^{18} \mathrm{O}$ records published by Arz et al. (1999).

Based on absolute SST and $\delta^{18} \mathrm{O}_{\text {ivc-ssw }}$ values from the NBC (Weldeab et al., 2006) and the BC (this study) we are now able to show that the HS1-LGM SST $\left(\delta^{18} \mathrm{O}_{\text {ivc-ssw }}\right)$ anomaly at the NBC site amounts to ca. $2.5^{\circ} \mathrm{C}$ and $0.5 \%$, respectively, while at our $\mathrm{BC}$ site it is limited to ca. $1.3{ }^{\circ} \mathrm{C}$ and $0.3 \%$, respectively. Thus, the NBC showed larger SST and $\delta^{18} \mathrm{O}_{\text {ivc-ssw }}$ increases when compared to the BC during HS1. Since temperature and $\delta^{18} \mathrm{O}_{\mathrm{sw}}$ influence foraminiferal $\delta^{18} \mathrm{O}$ in opposite directions, the signal of the stronger warming at the NBC was dampened by the larger increase in $\delta^{18} \mathrm{O}_{\mathrm{ivc}-\mathrm{ssw}}$, preventing the $\delta^{18} \mathrm{O}$ signal in $G$. ruber to change (assuming a $0.2 \% 0^{\circ} \mathrm{C}^{-1}$; Mulitza et al., 2003). So far, this stands for no $\mathrm{BC}-\mathrm{NBC}$ anomaly in foraminiferal $\delta^{18} \mathrm{O}$ during HS1. Nevertheless, our BC site is located ca. $12^{\circ}$ downstream of the sites investigated by Arz et al. (1999) in the BC. Because the north-south SST gradient in the western South Atlantic was larger than the one for $\delta^{18} \mathrm{O}_{\text {ivc-ssw }}$ during HS1, it is expected that a larger warming at the southern sites studied by Arz et al. (1999) overprinted the $\delta^{18} \mathrm{O}_{\text {ivc-ssw }}$ effect and produced the reported negative excursion in foraminiferal $\delta^{18} \mathrm{O}$.

Together with the NBC record, our SST reconstruction provides evidence that the western South Atlantic was indeed affected by Northern Hemisphere rapid climate change during Termination 1. However, the thermal response of the surface layer of the western South Atlantic cannot be described as an anti-phase in SST between the BC and the NBC regions (Arz et al., 1999) but rather as a widespread and in-phase increase in SST.
The low SSTs from our record during the Younger Dryas (YD) do not agree with the high temperatures reported by Weldeab et al. (2006) for the same event (Fig. 5c, d). The inconsistency of the YD SST signal in the western South Atlantic may be due to (i) the smaller amplitude of the AMOC slowdown that characterized the YD when compared to HS1 (McManus et al., 2004; Ritz et al., 2013); (ii) the shorter duration of the YD when compared to HS1 (EPICA Community Members, 2006; Rasmussen et al., 2006; Sarnthein et al., 2001) related to the time needed for the South Atlantic to equilibrate after an anomalous freshwater pulse in the high latitudes of the North Atlantic; and (iii) the different boundary conditions of the YD when compared to those present during HS1 (Clark et al., 2012). Numerical model experiments provide key insights into these three non-exclusive possibilities. First, water-hosing model experiments that retain an active and relatively strong AMOC indeed showed a much weaker expression of the bipolar seesaw when compared to simulations in which the AMOC strongly decreases (Kageyama et al., 2013; Otto-Bliesner and Brady, 2010). Second, the reduction of the AMOC intensity due to freshwater perturbation increases with increasing duration and amount of the freshwater perturbation (Rind et al., 2001; Prange et al., 2002). Third, freshwater discharge to different geographic regions in the North Atlantic has been shown to trigger different responses in the AMOC (Roche et al., 2009; Otto-Bliesner and Brady, 2010). Thus, all three possibilities may have acted together or independently, producing a different response of the western South Atlantic during the YD and HS1.

In addition to the bipolar seesaw, another mechanism that acts to cool the western South Atlantic during specific slowdown events of the AMOC seems to exist. This mechanism may be related to a change in the wind field, or more precisely to a weakening of the subtropical high-pressure cell (Prange and Schulz, 2004). Based on climate model results and proxy records from the Benguela upwelling region, Prange and Schulz (2004) suggested a weakening of the South Atlantic subtropical anticyclone in response to a reduced cross-equatorial Atlantic Ocean heat transport. This would result in a weakening of the $\mathrm{BC}$ and its associated heat transport from the tropics and hence a cooling at our core site. Which mechanism dominates (i.e., bipolar seesaw or wind field) may depend on boundary conditions and freshwater forcing function.

A similar thermal evolution spanning most of Termination 1 (i.e., HS1 and BA) is a pervasive feature not only of the western South Atlantic (this study; Weldeab et al., 2006) but also of the southernmost eastern South Atlantic, as reconstructed from a core raised at $4981 \mathrm{~m}$ water depth at $41.10^{\circ} \mathrm{S}$, $7.80^{\circ} \mathrm{E}$ (Fig. 5e) (Barker et al., 2009). The high-temporalresolution $\mathrm{Mg}$ / Ca-based SST record from the southernmost eastern South Atlantic also presents high SSTs during HS1 that are followed by a marked drop at ca. 14 cal ka BP and increasing temperatures towards the onset of the YD (Barker et 
al., 2009). The striking similarity of the three high-temporalresolution (i.e., 150 years or less between adjacent samples) $\mathrm{Mg} / \mathrm{Ca}-\mathrm{based}$ SST records from the South Atlantic (this study; Weldeab et al., 2006; Barker et al., 2009) not influenced by continental margin upwelling (Farmer et al., 2005) or continental freshwater discharge (Weldeab et al., 2007) suggests an emerging South Atlantic-wide pattern in SST evolution during most of Termination 1. Still, the view of the YD as a replicate of HS1 seems not to hold for the western South Atlantic.

Recently, Weber et al. (2014) suggested that Antarctic meltwater pulses may have cooled the upper water column of the South Atlantic. Indeed, our sea surface temperature record shows minor (i.e., ca. $0.5^{\circ} \mathrm{C}$ ) decreases around the two most prominent events of increased flux of iceberg-rafted debris at the Scotia Sea (a proxy for Antarctic meltwater pulses) recorded during Termination 1 (i.e., Antarctic Ice Sheet discharge (AID) event 7 between 16.91 and $15.75 \mathrm{cal} \mathrm{ka} \mathrm{BP}$, and event AID6 between 14.86 and 13.94 cal ka BP) (Chiessi et al., 2015a). Thus, Antarctic meltwater pulses may have contributed to the variability in SST from the subtropical domain of the Brazil Current on top of the mechanisms already described.

\subsection{Continental mean air temperatures over southeastern South America during Termination 1}

Most of the warming in our step-like structured MAT record takes place during the second half of HS1 and during the YD, but due to the marked decrease in temporal resolution of our MAT record after 14.1 cal ka BP we raise a note of caution while interpreting the temperature rise during the YD (Fig. 4e) (Sarnthein et al., 2001; Rasmussen et al., 2006). Our MAT record is remarkably similar to deglacial rise in atmospheric $\mathrm{CO}_{2}$ and Antarctic temperatures (Fig. 6c, d, e) (EPICA Community Members, 2006; Monnin et al., 2004). The timing of the two pulses of MAT increase in our record (i.e., ca. 16.5 and $12.5 \mathrm{cal} \mathrm{ka} \mathrm{BP}$ ) is synchronous with intervals of marked increases in global atmospheric $\mathrm{CO}_{2}$ and Antarctic temperatures, and the periods of relatively stable MAT are also contemporaneous with periods of a small rate of global atmospheric $\mathrm{CO}_{2}$ and Antarctic temperature increase. The two pulses of sharp increase in deglacial atmospheric $\mathrm{CO}_{2}$ also occurred simultaneously with increased upwelling in the Southern Ocean (Anderson et al., 2009). As suggested by Toggweiler et al. (2006), warming around Antarctica may have increased upwelling through a poleward shift in the Southern Westerlies and a corresponding increase in northward Ekman transport of surface waters. Still, the trigger for the changes in upwelling in the Southern Ocean probably resided in the high latitudes of the North Atlantic (i.e., HS1 and the YD) and was transmitted to the Southern Hemisphere via changes in atmospheric (Lee et al., 2011) or oceanic (Knutti et al., 2004) circulation.
Since atmospheric circulation in the LPRDB is dominated by northerly winds (Fig. 1b) (Kalnay et al., 1996), deglacial evolution of continental surface air temperature in the region is also expected to follow the mean warming trend of lowlatitude regions in South America. However, high-temporalresolution and continuous MAT records from tropical South America to the east of the Andes spanning most of Termination 1 are, to our knowledge, still absent, and highlight the uniqueness of our record (Shakun et al., 2012). The pollenderived temperature record from Lake Consuelo $\left(13.95^{\circ} \mathrm{S}\right)$, eastern Peru, is probably the temperature record with the highest resolution in the region (Fig. 6b) (Bush et al., 2004). The large variability and the low temporal resolution of that record for Termination 1 hampers any detailed correlation to our MAT record (Fig. 6b, c). Thus, a putative link in deglacial surface air temperature evolution between tropical and subtropical South America remains elusive.

The general agreement between our MAT record and the deglacial rise in atmospheric $\mathrm{CO}_{2}$ content (Monnin et al., 2004) (Fig. 6c, d) suggests that greenhouse gas concentrations exerted a strong control on the evolution of LPRDB MAT during Termination 1.

Additionally, Antarctic meltwater pulses may have decreased MAT over southeastern South America (Weber et al., 2014). The modeled cooling amounts to ca. $1.0^{\circ} \mathrm{C}$ over the southernmost portion of the LPRDB. Given age model uncertainties, the two most prominent events of increased flux of iceberg-rafted debris at the Scotia Sea (i.e., AID7 and AID6; Weber et al., 2014) partially correlate with negative anomalies in our MAT record (Chiessi et al., 2015a). Thus, Antarctic meltwater pulses may have contributed to the variability in MAT over the LPRDB in addition to changes in atmospheric $\mathrm{CO}_{2}$ concentration.

\subsection{Combining sea surface temperatures in the western South Atlantic and continental mean air temperatures on the adjacent continent during Termination 1}

Our SST record suggests that the South Atlantic, and the BC more specifically, was of paramount importance for the southward propagation of the thermal bipolar seesaw signal of HS1 (Fig. 5). Indeed, the western South Atlantic was more sensitive to AMOC forcing than lowland South America, which appears to be more susceptible to atmospheric $\mathrm{CO}_{2}$ changes (Figs. 5 and 6). Thus, our SST and MAT records sum up to other lines of evidence supporting the notion that global continental air temperature closely tracked the increase in atmospheric $\mathrm{CO}_{2}$ concentration during Termination 1, and that variations in the AMOC caused a seesawing of heat between the hemispheres mainly impacting the oceans in the Southern Hemisphere (Shakun et al., 2012).

Assuming no significant delay in the transport of the continental temperature signal to our core site (Weijers et al., 2007; Schefuss et al., 2011), our records allow for a phase 


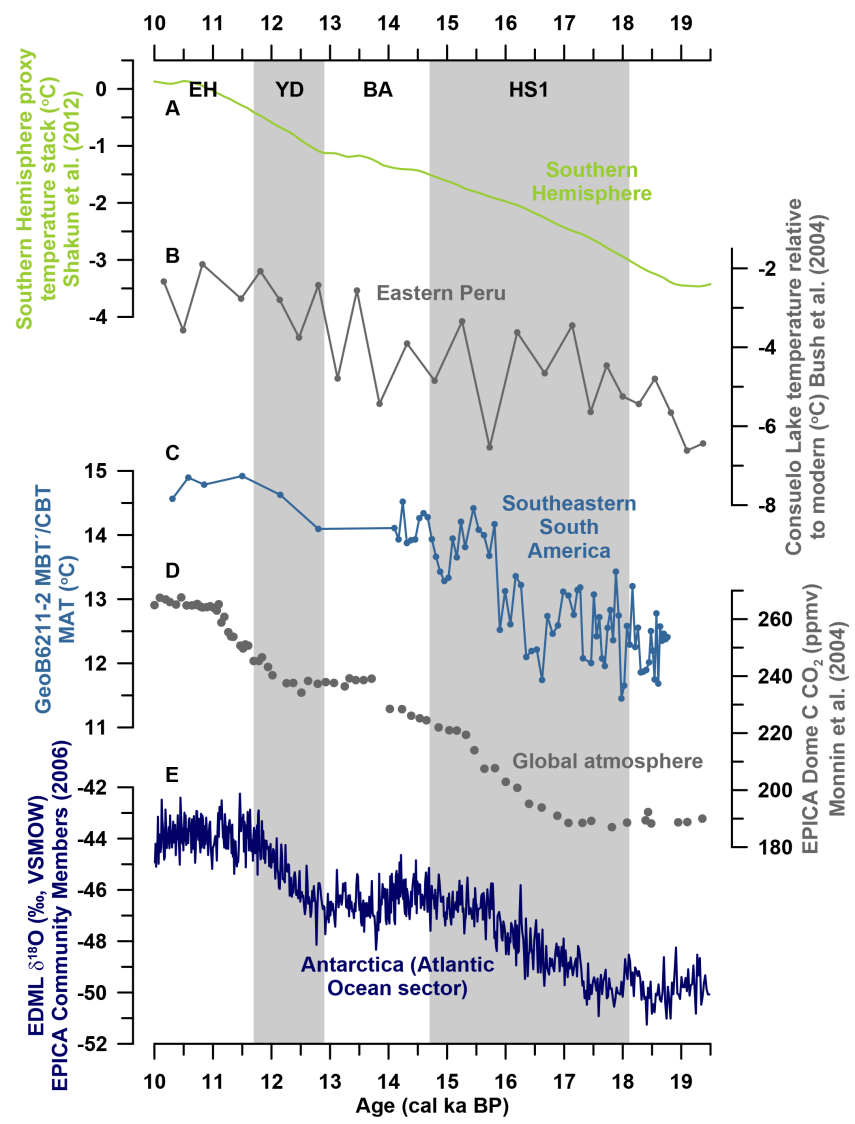

Figure 6. Millennial-scale variability of the mean air temperature of southeastern South America spanning Termination 1 compared to selected available records. (a) Southern Hemisphere proxy temperature stack (Shakun et al., 2012). (b) Lake Consuelo pollenbased temperature anomalies relative to modern conditions (Bush et al., 2004). (c) GeoB6211-2 methylation of branched tetraether (MBT')- and cyclization of branched tetraether (CBT)-based mean air temperature (MAT). (d) EPICA Dome C (Monnin et al., 2004) atmospheric $\mathrm{CO}_{2}$ plotted versus its original chronology. (e) EPICA Dronning Maud Land (EPICA Community Members, 2006) $\delta^{18} \mathrm{O}$ plotted versus its original chronology. Grey vertical bars depict Heinrich Stadial 1 (HS1) (Sarnthein et al., 2001) and the Younger Dryas (YD) (Rasmussen et al., 2006). BA: Bølling-Allerød; EH: early Holocene.

relationship to be established between changes in AMOC strength related to the onset of $\mathrm{HS} 1$ and the rise in atmospheric $\mathrm{CO}_{2}$. According to our records, the decrease in AMOC strength already impacted SST in the western South Atlantic as early as ca. 19 cal ka BP, while the rise in atmospheric $\mathrm{CO}_{2}$ only affected MAT at ca. $16.5 \mathrm{cal}$ ka BP. As suggested by Denton et al. (2010), the long duration of last deglaciation stadials was of fundamental importance to produce the necessary large oceanic $\mathrm{CO}_{2}$ release via the Southern Ocean (Anderson et al., 2009). Thus, increasing Northern Hemisphere summer insolation alone was insufficient to terminate the last glaciation, and the impact of rising atmo- spheric $\mathrm{CO}_{2}$ was a key factor to complete the last deglaciation (Denton et al., 2010; Shakun et al., 2012).

Interestingly, our SST and MAT records present different amplitudes in deglacial temperature rise. Similar to the oceanic and continental temperature records reported by Weijers et al. (2007), our oceanic temperatures (i.e., $1.6^{\circ} \mathrm{C}$ ) showed a smaller amplitude when compared to our continental temperatures (i.e., $2.5^{\circ} \mathrm{C}$ ) (Fig. $4 \mathrm{~b}, \mathrm{e}$ ). The deglacial amplitude of our SST record is very similar to global compilations (i.e., $1-2{ }^{\circ} \mathrm{C}$ ) (e.g., MARGO Project Members, 2009) and regional reconstructions (i.e., $1-2^{\circ} \mathrm{C}$ ) (Carlson et al., 2008; Toledo et al., 2007), even considering the lower temporal resolution of those reconstructions when compared to our record.

On the other hand, the deglacial amplitude of our MAT record is remarkably smaller than the amplitude of the few other available continental records for tropical South America, namely $5-7^{\circ} \mathrm{C}$ from Behling (2002) and 5-9 ${ }^{\circ} \mathrm{C}$ from Bush et al. (2004). Nevertheless, pollen-based tropical and subtropical temperature reconstructions should be interpreted with caution since changes in moisture availability may also impact the recorded signal.

The difference between oceanic and continental warming during Termination 1 reported in this study agrees with climate model simulations that suggest an average continental deglacial warming in the tropics ca. 1.5 times higher than the deglacial warming of the tropical oceans (Otto-Bliesner et al., 2006; Braconnot et al., 2012). The land/sea warming ratio is usually explained through differences in evaporation between land and ocean, and through land-surface feedbacks (Braconnot et al., 2012).

\section{Conclusions}

Our SST record from the BC in the western South Atlantic shows a marked positive anomaly during HS1. This is the first record that corroborates model suggestions that the surface layer of the BC acted as an important conduit and storage volume for part of the heat not transported to the North Atlantic under a sluggish AMOC. Thus, the BC was of paramount importance in propagating southwards the thermal bipolar seesaw signal of HS1. Moreover, the marked similarity to a SST record from the NBC suggests an in-phase thermal evolution of the $\mathrm{BC}$ and the NBC during HS1 (and the BA), contradicting previous assumptions of a BC-NBC anti-phase. Similar changes in SST are not only a pervasive feature of the western South Atlantic but also of the southernmost eastern South Atlantic, suggesting a South Atlanticwide pattern in SST evolution during most of Termination 1. Over southeastern South America, our MAT record shows that most of the deglacial warming occurred during the second half of HS1 and during the YD. Changes in MAT are remarkably synchronous with atmospheric $\mathrm{CO}_{2}$ rise, suggesting that greenhouse gas concentrations exerted a strong con- 
trol on South American surface temperatures during Termination 1 . The ca. $2.5 \mathrm{kyr}$ lag of MAT rise when compared to SST rise after the LGM corroborates the notion that the long duration of HS1 was fundamental to drive the Earth out of the last glacial.

Acknowledgements. We thank M. Segl and S. Pape for their help with the isotope and trace element analyses, respectively. We thank W. Duleba, S. L. Ho and U. Merkel for discussion, and L. Barbara (reviewer), the anonymous reviewer and J. P. Bernal (editor) for constructive comments. Logistic and technical assistance was provided by the captain and crew of the R/V Meteor. C. M. Chiessi acknowledges the financial support from FAPESP (grant 2012/17517-3). This study was partially performed during a stay of C. M. Chiessi at the Hanse Institute for Advanced Study in Delmenhorst, Germany. S. Mulitza was funded through the DFG Research Centre/Cluster of Excellence "The Ocean in the Earth System". Sample material was provided by the GeoB Core Repository at the MARUM - Center for Marine Environmental Sciences, University of Bremen, Germany. The data reported in this paper will be archived in Pangaea (www.pangaea.de).

Edited by: J. P. Bernal

\section{References}

Anand, P., Elderfield, H., and Conte, M. H.: Calibration of $\mathrm{Mg} / \mathrm{Ca}$ thermometry in planktonic foraminifera from a sediment trap time series, Paleoceanography, 18, 1050, doi:10.1029/2002PA000846, 2003.

Anderson, R. F., Ali, S., Bradtmiller, L. I., Nielsen, S. H., Fleisher, M. Q., Anderson, B. E., and Burckle, L. H.: Wind-driven upwelling in the Southern Ocean and the deglacial rise in atmospheric $\mathrm{CO}_{2}$, Science, 323, 1443-1448, 2009.

Antonov, J. I., Seidov, D., Boyer, T. P., Locarnini, R. A., Mishonov, A. V., Garcia, H. E., Baranova, O. K., Zweng, M. M., and Johnson, D. R.: World Ocean Atlas 2009 Volume 2: Salinity, edited by: Levitus, S., NOAA Atlas NESDIS 69, US Gov. Printing Office, Washington, DC, 184 pp., 2010.

Arz, H. W., Pätzold, J., and Wefer, G.: The deglacial history of the western tropical Atlantic as inferred from high resolution stable isotope records off northeastern Brazil, Earth Planet. Sci. Lett., 167, 105-117, 1999.

Bard, E., Rostek, F., Turon, J.-L., and Gendreau, S.: Hydrological Impact of Heinrich Events in the Subtropical Northeast Atlantic, Science, 289, 1321-1324, 2000.

Barker, S., Greaves, M., and Elderfield, H.: A study of cleaning procedures used for foraminiferal $\mathrm{Mg} / \mathrm{Ca}$ paleothermometry, Geochem. Geophys. Geosys., 4, 8407, doi:10.1029/2003GC000559, 2003.

Barker, S., Diz, P., Vautravers, M. J., Pike, J., Knorr, G., Hall, I. R., and Broecker, W. S.: Interhemispheric Atlantic seesaw response during the last deglaciation, Nature, 457, 1097-1102, 2009.

Behling, H.: South and southeast Brazilian grasslands during Late Quaternary times: a synthesis, Palaeogeogr. Palaeoclimatol. Palaeoecol., 177, 19-27, 2002.
Berbery, E. H. and Barros, V. R.: The Hydrologic Cycle of the La Plata Basin in South America, J. Hydrometeorol., 3, 630-645, 2002.

Bond, G., Heinrich, H., Broecker, W., Labeyrie, L., McManus, J., Andrews, J., Huon, S., Jantschik, R., Clasen, S., Simet, C., Tedesco, K., Klas, M., Bonani, G., and Ivy, S.: Evidence for massive discharges of icebergs into the North Atlantic ocean during the last glacial period, Nature, 360, 245-249, 1992.

Braconnot, P., Harrison, S. P., Kageyama, M., Bartlein, P. J., Masson-Delmotte, V., Abe-Ouchi, A., Otto-Bliesner, B., and Zhao, Y.: Evaluation of climate models using palaeoclimatic data, Nat. Clim. Change, 2, 417-424, 2012.

Broecker, W.: Paleocean circulation during the last deglaciation: A bipolar seesaw?, Paleoceanography, 13, 119-121, 1998.

Bush, M. B., Silman, M. R., and Urrego, D. H.: 48000 years of climate and forest change in a biodiversity hot spot, Science, 303 , 827-829, 2004.

Carlson, A. E., Oppo, D. W., Came, R. E., LeGrande, A. N., Keigwin, L. D., and Curry, W. B.: Subtropical Atlantic salinity variability and Atlantic meridional circulation during the last deglaciation, Geology, 36, 991-994, 2008.

Carvalho, L. M. V., Jones, C., and Liebmann, B.: The South Atlantic Convergence Zone: intensity, form, persistence, and relationships with intraseasonal to interannual activity and extreme rainfall, J. Climate, 17, 88-109, 2004.

Chiang, J. C. H., Cheng, W., and Bitz, C. M.: Fast teleconnections to the tropical Atlantic sector from Atlantic thermohaline adjustment, Geophys. Res. Lett., 35, L07704, doi:10.1029/2008GL033292, 2008.

Chiessi, C. M., Ulrich, S., Mulitza, S., Pätzold, J., and Wefer, G.: Signature of the Brazil-Malvinas Confluence (Argentine Basin) in the isotopic composition of planktonic foraminifera from surface sediments, Mar. Micropaleontol., 64, 52-66, 2007.

Chiessi, C. M., Mulitza, S., Paul, A., Pätzold, J., Groeneveld, J., and Wefer, G.: South Atlantic interocean exchange as the trigger for the Bølling warm event, Geology, 36, 919-922, 2008.

Chiessi, C. M., Mulitza, S., Pätzold, J., Wefer, G., and Marengo, J. A.: Possible impact of the Atlantic Multidecadal Oscillation on the South American summer monsoon, Geophys. Res. Lett., 36, L21707, doi:10.1029/2009g1039914, 2009.

Chiessi, C. M., Mulitza, S., Groeneveld, J., Silva, J. B., Campos, M. C., and Gurgel, M. H. C.: Variability of the Brazil Current during the late Holocene, Palaeogeogr. Palaeoclimatol. Palaeoecol., 415, 28-36, 2014.

Chiessi, C. M., Mulitza, S., Mollenhauer, G., Silva, J. B., Groeneveld, J., Prange, M.: Interactive comment on "Thermal evolution of the western South Atlantic and the adjacent continent during Termination 1" by C. M. Chiessi et al., Clim. Past Discuss., 10, C2489-C2489, 2015a

Chiessi, C. M., Mulitza, S., Mollenhauer, G., Silva, J. B., Groeneveld, J., and Prange, M.: Interactive comment on "Thermal evolution of the western South Atlantic and the adjacent continent during Termination 1" by C. M. Chiessi et al., Clim. Past Discuss., C2490-C2490, 2015b.

Clark, P. U., Shakun, J. D., Baker, P. A., Bartlein, P. J., Brewer, S., Brook, E., Carlson, A. E., Cheng, H., Kaufman, D. S., Liu, Z., Marchitto, T. M., Mix, A. C., Morrill, C., Otto-Bliesner, B. L., Pahnke, K., Russell, J. M., Whitlock, C., Adkins, J. F., Blois, J. L., Clark, J., Colman, S. M., Curry, W. B., Flower, B. P., He, 
F., Johnson, T. C., Lynch-Stieglitz, J., Markgraf, V., McManus, J., Mitrovica, J. X., Moreno, P. I., and Williams, J. W.: Global climate evolution during the last deglaciation, Proc. Natl. Acad. Sci., 109, E1134-E1142, 2012.

Crowley, T. J.: North Atlantic Deep Water cools the southern hemisphere, Paleoceanography, 7, 489-497, 1992.

Crowley, T. J.: Proximal trigger for late glacial Antarctic circulation and $\mathrm{CO}_{2}$ changes, 19, 70-71, PAGES news, 2011.

Denton, G. H., Anderson, R. F., Toggweiler, J. R., Edwards, R. L., Schaefer, J. M., and Putnam, A. E.: The last glacial termination, Science, 328, 1652-1656, 2010.

Depetris, P. J. and Kempe, S.: Carbon dynamics and sources in the Paraná River, Limnol. Oceanogr., 38, 382-395, 1993.

Depetris, P. J., Probst, J.-L., Pasquini, A. I., and Gaiero, D. M.: The geochemical characteristics of the Paraná River suspended sediment load: an initial assessment, Hydrol. Proc., 17, 1267-1277, 2003.

Deschamps, P., Durand, N., Bard, E., Hamelin, B., Camoin, G., Thomas, A. L., Henderson, G. M., Okuno, J., and Yokoyama, Y.: Ice-sheet collapse and sea-level rise at the Bolling warming 14600 years ago, Nature, 483, 559-564, 2012.

EPICA Community Members: One-to-one coupling of glacial climate variability in Greenland and Antarctica, Nature, 7116, 195198, 2006.

Farmer, E. C., deMenocal, P. B., and Marchitto, T. M.: Holocene and deglacial ocean temperature variability in the Benguela upwelling region: Implications for low-latitude atmospheric circulation, Paleoceanography, 20, PA2018, doi:10.1029/2004pa001049, 2005.

Fraile, I., Mulitza, S., and Schulz, M.: Modeling planktonic foraminiferal seasonality: Implications for sea-surface temperature reconstructions, Mar. Micropaleontol., 72, 1-9, 2009a.

Fraile, I., Schulz, M., Mulitza, S., Merkel, U., Prange, M., and Paul, A.: Modeling the seasonal distribution of planktonic foraminifera during the Last Glacial Maximum, Paleoceanography, 24, PA2216, doi:10.1029/2008PA001686, 2009b.

Garreaud, R. D., Vuille, M., Compagnucci, R., and Marengo, J.: Present-day South American climate, Palaeogeogr. Palaeoclimatol. Palaeoecol., 281, 180-195, 2009.

Greaves, M., Caillon, N., Rebaubier, H., Bartoli, G., Bohaty, S., Cacho, I., Clarke, L., Cooper, M., Daunt, C., Delaney, M., deMenocal, P., Dutton, A., Eggins, S., Elderfield, H., GarbeSchoenberg, D., Goddard, E., Green, D., Groeneveld, J., Hastings, D., Hathorne, E., Kimoto, K., Klinkhammer, G., Labeyrie, L., Lea, D. W., Marchitto, T., Martínez-Botí, M. A., Mortyn, P. G., Ni, Y., Nuernberg, D., Paradis, G., Pena, L., Quinn, T., Rosenthal, Y., Russell, A., Sagawa, T., Sosdian, S., Stott, L., Tachikawa, K., Tappa, E., Thunell, R., and Wilson, P. A.: Interlaboratory comparison study of calibration standards for foraminiferal $\mathrm{Mg}$ / Ca thermometry, Geochemistry, Geophysics, Geosystems, 9, Q08010, doi:10.1029/2008gc001974, 2008.

Groeneveld, J. and Chiessi, C. M.: $\mathrm{Mg} / \mathrm{Ca}$ of Globorotalia inflata as a recorder of permanent thermocline temperatures in the South Atlantic, Paleoceanography, 26, PA2203, doi:10.1029/2010pa001940, 2011.

Hönisch, B., Allen, K. A., Lea, D. W., Spero, H. J., Eggins, S. M., Arbuszewski, J., deMenocal, P., Rosenthal, Y., Russell, A. D., and Elderfield, H.: The influence of salinity on $\mathrm{Mg} / \mathrm{Ca}$ in planktic foraminifers - Evidence from cultures, core-top sedi- ments and complementary $\delta^{18} \mathrm{O}$, Geochim. Cosmochim. Acta, 121, 196-213, 2013.

Hopmans, E. C., Weijers, J. W. H., Schefuß, E., Herfort, L., Sinninghe Damsté, J. S., and Schouten, S.: A novel proxy for terrestrial organic matter in sediments based on branched and isoprenoid tetraether lipids, Earth Planet. Sci. Lett., 224, 107-116, 2004.

Hughen, K. A., Baillie, M. G. L., Bard, E., Beck, J. W., Bertrand, C. J. H., Blackwell, P. G., Buck, C. E., Burr, G. S., Cutler, K. B., Damon, P. E., Edwards, R. L., Fairbanks, R. G., Friedrich, M., Guilderson, T. P., Kromer, B., McCormac, G., Manning, S., Ramsey, C. B., Reimer, P. J., Reimer, R. W., Remmele, S., Southon, J. R., Stuiver, M., Talamo, S., Taylor, F. W., Van der Plicht, J., and Weyhenmeyer, C. E.: Marine04 marine radiocarbon age calibration, 0-26 cal kyr BP, Radiocarbon, 46, 1059-1086, 2004.

Hut, G.: Consultants group meeting on stable isotope reference samples for geochemical and hydrological investigations, International Atomic Energy Agency, Vienna, 42 pp., 1987.

Kageyama, M., Merkel, U., Otto-Bliesner, B., Prange, M., AbeOuchi, A., Lohmann, G., Ohgaito, R., Roche, D. M., Singarayer, J., Swingedouw, D., and Zhang, X.: Climatic impacts of fresh water hosing under Last Glacial Maximum conditions: a multimodel study, Clim. Past, 9, 935-953, doi:10.5194/cp-9-9352013, 2013.

Kalnay, E., Kanamitsu, M., Kistler, R., Collins, W., Deaven, D., Gandin, L., Iredell, M., Saha, S., White, G., Woollen, J., Zhu, Y., Leetmaa, A., Reynolds, R., Chelliah, M., Ebisuzaki, W., Higgins, W., Janowiak, J., Mo, K. C., Ropelewski, C., Wang, J., Jenne, R., and Joseph, D.: The NCEP/NCAR 40-Year Reanalysis Project, Bull. Am. Meteorol. Soc., 77, 437-471, 1996.

Knutti, R., Fluckiger, J., Stocker, T. F., and Timmermann, A.: Strong hemispheric coupling of glacial climate through freshwater discharge and ocean circulation, Nature, 430, 851-856, 2004.

Lambeck, K. and Chappell, J.: Sea level change through the last glacial cycle, Science, 292, 679-686, 2001.

Lantzsch, H., Hanebuth, T. J. J., Chiessi, C. M., Schwenk, T., and Violante, R. A.: The high-supply, current-dominated continental margin of southeastern South America during the late Quaternary, Quaternary Res., 81, 339-354, 2014.

Lee, S.-Y., Chiang, J. C. H., Matsumoto, K., and Tokos, K. S.: Southern Ocean wind response to North Atlantic cooling and the rise in atmospheric $\mathrm{CO}_{2}$ : Modeling perspective and paleoceanographic implications, Paleoceanography, 26, PA1214, doi:10.1029/2010pa002004, 2011.

Legates, D. R. and Willmott, C. J.: Mean seasonal and spatial variability in global surface air temperature, Theor. Appl. Climatol., 41, 11-21, 1990.

Locarnini, R. A., Mishonov, A. V., Antonov, J. I., Boyer, T. P., Garcia, H. E., Baranova, O. K., Zweng, M. M., and Johnson, D. R.: World Ocean Atlas 2009, Volume 1: Temperature, edited by: Levitus, S., NOAA Atlas NESDIS 68, U.S. Government Printing Office, Washington, DC, 184 pp., 2010.

Lombard, F., Labeyrie, L., Michel, E., Bopp, L., Cortijo, E., Retailleau, S., Howa, H., and Jorissen, F.: Modelling planktic foraminifer growth and distribution using an ecophysiological multi-species approach, Biogeosciences, 8, 853-873, doi:10.5194/bg-8-853-2011, 2011. 
Maier-Reimer, E., Mikolajewicz, U., and Crowley, T.: Ocean GCM sensitivity experiment with an open Central American Isthmus, Paleoceanography, 5, 349-366, 1990.

Manabe, S. and Stouffer, R. J.: Two Stable Equilibria of a Coupled Ocean-Atmosphere Model, J. Climate, 1, 841-866, 1988.

MARGO Project Members: Constraints on the magnitude and patterns of ocean cooling at the Last Glacial Maximum, Nat. Geosci., 2, 127-132, 2009.

Martrat, B., Jimenez-Amat, P., Zahn, R., and Grimalt, J. O.: Similarities and dissimilarities between the last two deglaciations and interglaciations in the North Atlantic region, Quaternary Sci. Rev., 99, 122-134, 2014.

McManus, J. F., Francois, R., Gherardi, J. M., Keigwin, L. D., and Brown-Leger, S.: Collapse and rapid resumption of Atlantic meridional circulation linked to deglacial climate changes, Nature, 428, 834-837, 2004.

Mix, A., Ruddiman, W. F., and McIntyre, A.: Late Quaternary paleoceanography of the tropical Atlantic, 1: Spatial variability of annual mean sea-surface temperatures, 0-20,000 years B.P., Paleoceanography, 1, 43-66, 1986.

Mohtadi, M., Prange, M., Oppo, D.W., De Pol-Holz, R., Merkel, U., Zhang, X., Steinke, S., and Lückge, A.: North Atlantic forcing of tropical Indian Ocean climate, Nature, 509, 76-80, 2014.

Monnin, E., Steig, E. J., Siegenthaler, U., Kawamura, K., Schwander, J., Stauffer, B., Stocker, T. F., Morse, D. L., Barnola, J.M., Bellier, B., Raynaud, D., and Fischer, H.: Evidence for substantial accumulation rate variability in Antarctica during the Holocene, through synchronization of $\mathrm{CO}_{2}$ in the Taylor Dome, Dome C and DML ice cores, Earth Planet. Sci. Lett., 224, 45-54, 2004.

Mulitza, S., Boltovskoy, D., Donner, B., Meggers, H., Paul, A., and Wefer, G.: Temperature: $\delta^{18} \mathrm{O}$ relationships of planktonic foraminifera collected from surface waters, Palaeogeogr. Palaeoclimatol. Palaeoecol., 202, 143-152, 2003.

NGRIP members: High-resolution record of Northern Hemisphere climate extending into the last interglacial period, Nature, 431, 147-151, 2004.

Olson, D. B., Podestá, G. P., Evans, R. H., and Brown, O. B.: Temporal variations in the separation of Brazil and Malvinas Currents, Deep-Sea Res. Pt. A, 35, 1971-1990, 1988.

Otto-Bliesner, B., Brady, E., Clauzet, G., Tomas, R., Levis, S., and Kothavala, Z.: Last Glacial Maximum and Holocene Climate in CCSM3, J. Climate, 19, 2529-2547, 2006.

Otto-Bliesner, B. L. and Brady, E. C.: The sensitivity of the climate response to the magnitude and location of freshwater forcing: last glacial maximum experiments, Quaternary Sci. Rev., 29, 56-73, 2010.

Peterse, F., van der Meer, J., Schouten, S., Weijers, J. W. H., Fierer, N., Jackson, R. B., Kim, J.-H., and Sinninghe Damsté, J. S.: Revised calibration of the MBT-CBT paleotemperature proxy based on branched tetraether membrane lipids in surface soils, Geochim. Cosmochim. Acta, 96, 215-229, 2012.

Peterson, R. G. and Stramma, L.: Upper-level circulation in the South Atlantic Ocean, Prog. Oceanogr., 26, 1-73, 1991.

Prange, M. and Schulz, M.: A coastal upwelling seesaw in the Atlantic Ocean as a result of the closure of the Central American Seaway, Geophys. Res. Lett., 31, L17207, doi:10.1029/2004g1020073, 2004.
Prange, M., Romanova, V., and Lohmann, G.: The glacial thermohaline circulation: Stable or unstable?, Geophys. Res. Lett., 29, 2028, doi:10.1029/2002GL015337, 2002.

Rasmussen, S. O., Andersen, K. K., Svensson, A. M., Steffensen, J. P., Vinther, B. M., Clausen, H. B., Siggaard-Andersen, M. L., Johnsen, S. J., Larsen, L. B., Dahl-Jensen, D., Bigler, M., Röthlisberger, R., Fischer, H., Goto-Azuma, K., Hansson, M. E., and Ruth, U.: A new Greenland ice core chronology for the last glacial termination, J. Geophys. Res., 111, D06102, doi:10.1029/2005jd006079, 2006.

Razik, S., Chiessi, C. M., Romero, O. E., and von Dobeneck, T.: Interaction of the South American Monsoon System and the Southern Westerly Wind Belt during the last 14 kyr, Palaeogeogr. Palaeoclimatol. Palaeoecol., 374, 28-40, 2013.

Reimer, P. J. and Reimer, R. W.: A marine reservoir correction database and on-line interface, Radiocarbon, 34, 461-463, 2001.

Reimer, P. J., Baillie, M. G. L., Bard, E., Bayliss, A., Beck, J. W., Blackwell, P. G., Ramsey, C. B., Buck, C. E., Burr, G. S., Edwards, R. L., Friedrich, M., Grootes, P. M., Guilderson, T. P., Hajdas, I., Heaton, T. J., Hogg, A. G., Hughen, K. A., Kaiser, K. F., Kromer, B., McCormac, F. G., Manning, S. W., Reimer, R. W., Richards, D. A., Southon, J. R., Talamo, S., Turney, C. S. M., Van der Plicht, J., and Weyhenmeyer, C. E.: IntCal09 and Marine09 radiocarbon age calibration curves, 0-50 000 years cal BP, Radiocarbon, 51, 1111-1150, 2009.

Reimer, P. J., Bard, E., Bayliss, A., Beck, J. W., Blackwell, P. G., Ramsey, C. B., Buck, C. E., Cheng, H., Lawrence Edwards, R., Friedrich, M., Grootes, P. M., Guilderson, T. P., Haflidason, H., Hajdas, I., Hatte, C., Heaton, T. J., Hoffmann, D. L., Hogg, A. G., Hughen, K. A., Kaiser, K. F., Kromer, B., Manning, S. W., Niu, M., Reimer, R. W., Richards, D. A., Scott, E. M., Southon, J. R., Staff, R. A., Turney, C. S. M., and Van der Plicht, J.: IntCal13 and Marine13 radiocarbon age calibration curves 0-50 000 years cal BP, Radiocarbon, 55, 1869-1887, 2013.

Rind, D., Russell, G., Schmidt, G., Sheth, S., Collins, D., deMenocal, P., and Teller, J.: Effects of glacial meltwater in the GISS coupled atmosphere-ocean model: 2. A bipolar seesaw in Atlantic Deep Water production, J. Geophys. Res.-Atmos., 106, 27355-27365, 2001.

Rintoul, S. R.: South Atlantic interbasin exchange, J. Geophys. Res., 96, 2675-2692, doi:10.1029/90jc02422, 1991.

Ritz, S. P., Stocker, T. F., Grimalt, J. O., Menviel, L., and Timmermann, A.: Estimated strength of the Atlantic overturning circulation during the last deglaciation, Nat. Geosci., 6, 208-212, 2013.

Roche, D. M., Wiersma, A. P., and Renssen, H.: A systematic study of the impact of freshwater pulses with respect to different geographical locations, Clim. Dynam., 34, 997-1013, 2009.

Sarnthein, M., Stattegger, K., Dreger, D., Erlenkeuser, H., Grootes, P., Haupt, b., Jung, S., Kiefer, T., Kuhnt, W., Pflaumann, U., Schäfer-Neth, C., Schulz, H., Schulz, M., Seidov, D., Simstich, J., van Kreveld, S., Vogelsang, E., Völker, A., and Weinelt, M.: Fundamental Modes and Abrupt Changes in North Atlantic Circulation and Climate over the last $60 \mathrm{ky}$ - Concepts, Reconstruction and Numerical Modeling, in: The Northern North Atlantic: A Changing Environment, edited by: Schäfer, P., Ritzrau, W., Schlüter, M., and Thiede, J., Springer, Berlin, 365-410, 2001.

Schefuss, E., Kuhlmann, H., Mollenhauer, G., Prange, M., and Patzold, J.: Forcing of wet phases in southeast Africa over the past 17000 years, Nature, 480, 509-512, 2011. 
Schlitzer, R.: Ocean Data View, available at: http://odv.awi.de, last access: 31 October 2014.

Schmidt, M. W., Chang, P., Hertzberg, J. E., Them, T. R., Ji, L., and Otto-Bliesner, B. L.: Impact of abrupt deglacial climate change on tropical Atlantic subsurface temperatures, Proc. Natl. Acad. Sci., 109, 14348-14352, 2012.

Schrag, D. P., Adkins, J. F., McIntyre, K., Alexander, J. L., Hodell, D. A., Charles, C. D., and McManus, J. F.: The oxygen isotopic composition of seawater during the Last Glacial Maximum, Quaternary Sci. Rev., 21, 331-342, 2002.

Schulz, H. D., Ayres Neto, A., Boetius, A., Enneking, K., Fabian, K., Feseker, T., Funk, J., Gorke, M., Heidersdorf, F., Hensen, C., Heuer, V., Hill, H. G., Hinrichs, S., Kasten, S., Klann, M., Lacerda de Souza, C., Martinez Briao, A., Meyer, S., Mulitza, S., Niebler, H.-S., Ochsenhirt, W.-T., Panteleit, B., Pfeifer, K., Schewe, F., Schwenk, T., Senorans, J. L., Siemer, S., Steinmetz, E., and Wenzhöfer, F.: Report and preliminary results of Meteor Cruise M46/2, Recife (Brazil) - Montevideo (Uruguay), 2 December - 29 December 1999, Fachbereich Geowissenschaften, Universität Bremen, Bremen, 107 pp., 2001.

Shakun, J. D., Clark, P. U., He, F., Marcott, S. A., Mix, A. C., Liu, Z., Otto-Bliesner, B., Schmittner, A., and Bard, E.: Global warming preceded by increasing carbon dioxide concentrations during the last deglaciation, Nature, 484, 49-54, 2012.

Stocker, T. F.: The seasaw effect, Science, 282, 61-62, 1998.

Stommel, H.: A survey of ocean current theory, Deep-Sea Res., 4, 149-184, 1957.

Stouffer, R. J., Yin, J., Gregory, J. M., Dixon, K. W., Spelman, M. J., Hurlin, W., Weaver, A. J., Eby, M., Flato, G. M., Hasumi, H., Hu, A., Jungclaus, J. H., Kamenkovich, I. V., Levermann, A., Montoya, M., Murakami, S., Nawrath, S., Oka, A., Peltier, W. R., Robitaille, D. Y., Sokolov, A., Vettoretti, G., and Weber, S. L.: Investigating the Causes of the Response of the Thermohaline Circulation to Past and Future Climate Changes, J. Climate, 19, 1365-1387, 2006.

Stramma, L. and England, M.: On the water masses and mean circulation of the South Atlantic Ocean, J. Geophys. Res.: Oceans, 104, 20863-20883, 1999.

Stramma, L., Ikeda, Y., and Peterson, R. G.: Geostrophic transport in the Brazil Current region north of $20^{\circ} \mathrm{S}$, Deep-Sea Res., 37 , 1875-1886, 1990.

Stramma, L., Fischer, J., and Reppin, J.: The North Brazil Undercurrent, Deep-Sea Res. Pt. I, 42, 773-795, 1995.

Stuiver, M. and Reimer, P. J.: Extended ${ }^{14} \mathrm{C}$ data base and revised CALIB 3.0 ${ }^{14} \mathrm{C}$ age calibration program, Radiocarbon, 35, 215230, 1993.

Toggweiler, J. R., Russell, J. L., and Carson, S. R.: Midlatitude westerlies, atmospheric $\mathrm{CO}_{2}$, and climate change during the ice ages, Paleoceanography, 21, PA2005, doi:10.1029/2005pa001154, 2006.
Toledo, F. A. L., Costa, K. B., and Pivel, M. A. G.: Salinity changes in the western tropical South Atlantic during the last $30 \mathrm{kyr}$, Glob. Planet. Change, 57, 383-395, 2007.

Vera, C. S., Vigliarolo, P. K., and Berbery, E. H.: Cold Season Synoptic-Scale Waves over Subtropical South America, Month. Weather Rev., 130, 684-699, 2002.

Wang, L.: Isotopic signals in two morphotypes of Globigerinoides ruber (white) from the South China Sea: implications for monsoon climate change during the last glacial cycle, Palaeogeogr. Palaeoclimatol. Palaeoecol., 161, 381-394, 2000.

Weber, M. E., Clark, P. U., Kuhn, G., Timmermann, A., Sprenk, D., Gladstone, R., Zhang, X., Lohmann, G., Menviel, L., Chikamoto, M. O., Friedrich, T., and Ohlwein, C.: Millennial-scale variability in Antarctic ice-sheet discharge during the last deglaciation, Nature, 510, 134-138, 2014.

Wefer, G., Adegbie, A. T., Böckel, B., Brauner, R., Büttner, U., Diekamp, V., Dillon, M., Dobeneck, T. v., Donner, B., Eberwein, A., Heinecke-Herzog, M., Kim, J. H., Meier, S., Mollenhauer, G., Olguin, H., Romero, O., Schewe, F., Schlemm, V., Schmieder, F., Schünemann, H., Streng, M., and Volbers, A. N. A.: Report and preliminary results of Meteor Cruise M46/4, Mar del Plata (Argentina) - Salvador da Bahia (Brazil), 10 February 13 March 2000, With partial results of Meteor Cruise M46/2., Fachbereich Geowissenschaften, Universität Bremen, Bremen, 136 pp., 2001.

Weijers, J. W., Schefuss, E., Schouten, S., and Sinninghe Damste, J. S.: Coupled thermal and hydrological evolution of tropical Africa over the last deglaciation, Science, 315, 1701-1704, 2007.

Weldeab, S., Schneider, R. R., and Kölling, M.: Deglacial sea surface temperature and salinity increase in the western tropical Atlantic in synchrony with high latitude climate instabilities, Earth Planet. Sci. Lett., 241, 699-706, 2006.

Weldeab, S., Lea, D. W., Schneider, R. R., and Andersen, N.: 155000 years of West African monsoon and ocean thermal evolution, Science, 316, 1303-1307, 2007.

Xie, P. and Arkin, P. A.: Global Precipitation: A 17-Year Monthly Analysis Based on Gauge Observations, Satellite Estimates, and Numerical Model Outputs, Bull. Am. Meteorol. Soc., 78, 25392558, 1997.

Yokoyama, Y., Lambeck, K., De Deckker, P., Johnston, P., and Fifield, L. K.: Timing of the Last Glacial Maximum from observed sea-level minima, Nature, 406, 713-716, 2000.

Zhou, J. and Lau, K. M.: Does a Monsoon Climate Exist over South America?, J. Climate, 11, 1020-1040, 1998.

Zhu, C., Weijers, J. W. H., Wagner, T., Pan, J. -M., Chen, J. -F., and Pancost, R. D.: Sources and distributions of tetraether lipids in surface sediments across a large river-dominated continental margin, Org. Geochem., 42, 376-386, 2011. 